\title{
PRESTIGIO POLÍTICO Y OFICIOS REALES: LA NOBLEZA CONQUENSE BAJOMEDIEVAL EN EL ENTORNO CORTESANO
}

\author{
POLITICAL PRESTIGE AND ROYAL OFFICES: \\ THE NOBILITY OF CUENCA \\ IN THE LATE MIDDLE AGES AT THE COURT
}

\author{
JosÉ IGNACIO ORTEGA CERVIGÓN \\ Universidad Complutense. Madrid
}

\begin{abstract}
Resumen: La nobleza conquense afianzó un patrimonio territorial y una notable posición política durante la baja Edad Media. Las relaciones establecidas con la monarquía le permitieron proyectar su ascenso socioeconómico - cargos concejiles, oficios cortesanos, donaciones señoriales - en una época de turbulencia social y política en los reinos peninsulares. En los linajes nobiliarios conquenses confluye un rasgo singular: el considerable número de sus integrantes que desempeñaron algún tipo de oficio regio, bien en el entorno cortesano, bien en tareas administrativas y territoriales. Estos oficios solían ser patrimonializados por un linaje a lo largo de varias generaciones y proporcionaban beneficios económicos y políticos.
\end{abstract}

Palabras clave: Nobleza; Castilla; Cuenca; Política; Corte; Oficios reales; Baja Edad Media.

\begin{abstract}
The nobility of Cuenca adquired a great territorial patrimony and a high political position during the Late Middle Ages. The complex relationship sustained by the Monarchy allowed them to project a socio-economic ascent - Town charges, courtly offices, seigneurial donations- in a time of social and political turbulence over the peninsular kingdoms. The noble lineages of Cuenca had a singular characteristic: a high number of their members developed a royal office in the court or in administrative and territorial functions. These offices used to be appropriated by a lineage for several generations and provided social as well as economic benefits.
\end{abstract}

Key words: Nobility; Castile; Cuenca; Policy; Court; Royal offices; Late Middle Ages.

\section{SUMARIO}

1. Introducción: nobleza y cargos reales en época trastámara.- 2. Oficios cortesanos desempeñados por la nobleza conquense. El Mayordomo mayor. El Guarda mayor y los guardas reales. El Ballestero mayor. El Montero mayor. El Halconero mayor. El Maestresala. El oficial del cuchillo. El Copero mayor. El Camarero mayor de las armas. Los donceles del rey.- 3. Otros cargos no cortesanos. El Alcalde mayor de los fijosdalgo de Castilla. El Alcalde entregador mayor de las mestas y las cañadas. El Adelantado de Cazorla. Los consejeros reales.- 4. Conclusiones.- Apéndice documental. 


\section{INTRODUCCIÓN: \\ NOBLEZA Y CARGOS REALES EN ÉPOCA TRASTÁMARA}

La participación de la nobleza castellana en el desempeño de distintos cargos y oficios del gobierno regio responde, primordialmente, a un deseo de legitimar y consolidar el poder político y los privilegios adquiridos a partir de la instauración de la dinastía Trastámara. De la intervención nobiliaria en los asuntos de la administración del reino castellano se derivaba un indudable beneficio económico en quitaciones y raciones, un aumento de su prestigio social y una capacidad de decisión en aspectos de gran interés colectivo e individual. Esta realidad era posible en el siglo XV porque aún se mantenía vigente un sistema de poder que reflejaba el orden feudal basado en relaciones personales vasalláticas ${ }^{1}$.

La patrimonialización de los oficios reales por parte de la nobleza fue una nota dominante del panorama político en la Castilla del siglo $\mathrm{XV}$, acentuada por la consolidación del mayorazgo como sistema de transmisión patrimonial nobiliario. Los cargos eran otorgados por el monarca como merced o compensación a un servicio prestado, generalmente de valía militar, y podía ser heredado por los sucesores, al ser considerado un bien familiar más. Vamos a analizar el caso paradigmático de los linajes conquenses ${ }^{2}$, que disfrutaron de un buen número de estos oficios cortesanos a lo largo de la baja Edad Media, lo que les permitió gozar de la confianza regia y consolidar tanto su ascenso político como su patrimonio económico, ya que percibían unos ingresos nada desdeñables ${ }^{3}$. Desde el prisma de la conformación del Estado moderno, la patrimonialización de los oficios públicos suponía un entorpecimiento para la eficacia de la gestión administrativa de Castilla, aunque fue un

${ }^{1}$ Remitimos a las acertadas directrices metodológicas e historiográficas que sobre este tema expone M. ${ }^{\mathrm{J}}$ J. GARCíA VERA, Poder nobiliario y poder político en la Corte de Enrique IV (14541474), "En la España Medieval", 16 (1993), pp. 223-237.

${ }^{2}$ La nobleza se asentó en el territorio conquense gracias a donaciones y mercedes regias, fue incrementando su patrimonio señorial - afianzado gracias a la fundación de mayorazgos que garantizaron la transmișión de su poder económico y social- y disfrutó de una privilegiada posición política en la ciudad, donde desempeñó relevantes cargos concejiles. Esta temática ha constituido la investigación central de mi tesis doctoral, "La acción política y la proyección señorial de la nobleza territorial en el obispado de Cúenca durante la baja Edad Media", desarrollada bajo la dirección de la Prof ${ }^{\mathrm{a}} \mathrm{M}^{\mathrm{a}}$ Concepción Quintanilla Raso y defendida en la Universidad Complutense de Madrid en junio de 2006.

${ }^{3}$ Para los cargos que componían la Casa Real ver los trabajos de J. de SAlazAR Y ACHA, La Casa del Rey de Castilla y León en la Edad Media, Madrid, Centro de Estudios Políticos y Constitucionales, 2000, M.A. LADERO QUESADA, La Casa Real en la Baja Edad Media, "Historia. Instituciones. Documentos" 25 (1998), pp 327-356, M. a J. GARCíA VERA, La nobleza en la sociedad de Corte de Enrique IV (1454-1474). Una perspectiva de aproximación, en La nobleza peninsular en la Edad Media, VI Congreso de Estudios Medievales, León, Fundación Sánchez Albornoz, 1999, pp. 549-561 y A. FERNÁNDEZ DE CóRDOVA MIRALLES, La Corte de Isabel I. Ritos y ceremonias de una reina, Madrid, Dykinson, 2002. 
fenómeno habitual en los reinos europeos, especialmente en el ámbito concejil y local ${ }^{4}$.

Los linajes conquenses podrían encuadrarse dentro de la etiqueta de "nobleza de servicio", término acuñado para designar a los linajes castellanos que se encumbraron a los primeros niveles de la actuación gubernamental durante el reinado de Enrique III, gracias a la percepción de títulos, rentas y cargos concedidos por la monarquía 5 . Aun considerando que la nobleza conquense tuvo un protagonismo secundario en el devenir de los principales acontecimientos políticos del reino castellano, conviene apuntar en ella una serie de rasgos comunes: acumulación de un patrimonio señorial en la comarca, diversidad en las fuentes de ingresos económicos, estrategias matrimoniales afines y aspiraciones políticas en los marcos urbano y cortesano. En este último aspecto destaca el desempeño de determinados cargos y oficios cortesanos, que eran traspasados en numerosas ocasiones de forma hereditaria a miembros del mismo linaje. Los principales linajes conquenses de época trastámara fueron los Albornoz, los Hurtado de Mendoza, señores de Cañete, los Carrillo de Albornoz, señores de Torralba y Beteta, los Carrillo de Mendoza, condes de Priego, los Acuña, condes de Buendía, y los Cabrera, marqueses de Moya ${ }^{6}$, cuyos titulares desempeñaron distintos oficios cortesanos y disfrutaron de títulos nobiliarios ${ }^{7}$.

${ }^{4} \mathrm{~F}$. TOMÁS Y VALIENTE, Origen bajomedieval de la patrimonialización y enajenación de los oficios públicos en Castilla, en "Actas del I Simposium de la Historia de la Administración", Madrid, 1970, pp 125-159. Sobre los abusos cometidos en la gestión de cargos y oficios públicos de nivel intermedio ver los artículos de M.C. CARLÉ, La corrupción en la función pública. Castilla siglo $X V$ " "Estudios de Historia de España", 3 (1990), p. p. 131-158 y. A. RIESCO TERRERO, Los oficios públicos de gobierno, administración, justicia y recaudación y los de garantía de la fe documental a la luz de una disposición en tiempos de los Reyes Católicos de finales del siglo XV (a. 1494), "Documenta \& Instrumenta", 3 (2005), pp. 77-108.

${ }^{5}$ Una visión sintética de la actuación del grupo nobiliario castellano en el contexto político de la época en la obra de M.-C. GERBET, Las noblezas españolas en la Edad Media. Siglos XI-XV, Madrid, Alianza Universidad, 1997, pp. 182 y ss.

${ }^{6}$ Algunas consideraciones sobre estos señoríos en los trabajos de S. de Moxó, Los Albornoz. La elevación de un linaje y su expansión dominical en el siglo XIV, en El Cardenal Albornoz y el Colegio de España, vol. I, Zaragoza, 1972, pp. 17-80; C. MIGNOT, Evolución de la estructura jurisdiccional en la región al carrena (siglos XI-XV), "Hispania", XLVI/163 (1986), pp. 245-281: $\mathrm{M}^{\mathrm{a}} \mathrm{C}$. QUINTANILl RASO, El condado de Priego de Cuenca. Un ejemplo de estrategia señoria en la Baja Edad Media castellana, "Historia. Instituciones. Documentos", 19 (1992), pp. 381402; Marcos y formas de proyección de la nobleza conquense en su entorno urbano y territorial, "Congreso Internacional de Historia. El Tratado de Tordesillas y su época”, Valladolid, 1995, I, pp. 131-154; Estructuras y relaciones de poder en la tierra de Cuenca 'a fines de la Edad Media, en La Península Iberica en la Era de los Descubrimientos (1391-1492), "Actas III Jornadas Hispano-Portuguesas de Historia Medieval”, Sevilla, 1997, I, pp. 707-736; Implantación de la nobleza en la tierra de Cuenca, en J.S. García Marchante y A. L. López Villaverde (coords.), Relaciones de poder en Castilla: el ejemplo de Cuenca, Cuenca, Universidad de Castilla-La Mancha, 1997, pp. 103-132, y J.I. ORTEGA CERVIGÓN, La proyección política y señorial de los Hurtado de Mendoza en Cuenca y su tierra durante el siglo XV en II ${ }^{O S}$ y III ${ }^{o s}$ Premios de Investigación Juan Giménez de Aguilar, Cuenca, 2003, pp. 9-84; Títulos, señoríos y poder: los grandes estados señoriales en la Castilla centro-oriental, en $\mathrm{M}^{\mathrm{a}} \mathrm{C}$. Quintanilla Raso (dir.), Títulos, Grandes del reino y grandeza en la sociedad política. Fundamentos en la Castilla medieval, Madrid, Sílex, 2006, pp. 265-307 y El arraigo de los linajes portugueses en la Castilla bajomedieval: el caso de los Acuña en el obispado de Cuenca, "Medievalismo", 16 (2006), pp. 73-92.

${ }^{7} \mathrm{M}^{\mathrm{a}} \mathrm{C}$. Quintanilla Raso,"Los grandes nobles", El mundo social de Isabel la Católica, "Medievalismo", 13-14 (2004), pp. 138-141. 


\title{
2. OFICIOS CORTESANOS \\ DESEMPEÑADOS POR LA NOBLEZA CONQUENSE
}

\section{El Mayordomo mayor}

En su origen, el Mayordomo mayor era el primer oficial al frente de la Casa del rey y estaba encargado de dirigir los servicios palatinos y la administración de la Hacienda regia. La evolución administrativa bajomedieval creó otras categorías que fueron cumpliendo las funciones del Mayordomo mayor - tesorero, despensero, camarero, copero, etc._-, aunque su dignidad siempre recayó en miembros de la alta nobleza castellana. Para desarrollar los cometidos tradicionales del Mayordomo mayor apareció la figura del mayordomo de la Casa del rey, que era más modesta y dependía del Contador mayor, ocupándose de la organización económica de la misma ${ }^{8}$. Entre la nobleza conquense hay varios personajes que disfrutaron de este cargo, como Álvar García de Albornoz, en época de Enrique II, Juan Hurtado de Mendoza - cuyo primogénito fue el primer señor de Cañete-, en tiempos de Enrique III, y Andrés de Cabrera, durante el reinado de Enrique IV (entre 1462 y 1474) y los Reyes Católicos.

El duque de Benavente y el arzobispo de Toledo pidieron como rehén, entre otros, un hijo de Juan Hurtado de Mendoza, Mayordomo mayor, para ir a las Cortes de Burgos de 1391 con garantías. . Un año después, en 1392, en el lugar de Perales se acordó

\begin{abstract}
que los seis tutores que el rey don Juan dejara nombrados en su testamento, es a saber, el marqués de Villena, e los arzobispos de Toledo e Santiago, e el maestre de Calatrava, e el conde de Niebla, e Juan Furtado de Mendoza, gobernasen el regno con los procuradores de seis cibdades. Además se añadieron el duque de Benavente, e el conde don Pedro, e el maestre de Santiago, porque todos estos grandes oviesen parte en el regimiento.
\end{abstract}

Se quiso alterar el testamento original del rey, pero finalmente el monarca Juan I encomendó a los seis tutores hacerse cargo del infante, entre los que se encontraba Juan Hurtado de Mendoza, Alférez mayor. El marqués de Villena recibiría 100.000 mrs., los arzobispos de Toledo y de Santiago 80.000 mrs., mientras que el maestre de Calatrava, el conde don Juan Alfonso y Juan Hurtado de Mendoza, 70.000 mrs. cada uno. También estaba previsto

${ }^{8} \mathrm{M}^{\mathrm{a}} \mathrm{J}$. GARCÍA VERA, La nobleza en la sociedad de Corte de Enrique IV (1454-1474). Una perspectiva de aproximación, ob. cit., pp. 556-557 y Poder nobiliario y poder político en la Corte de Enrique IV (1454-1474), ob. cit. pp. 229-230. El oficio de Mayordomo mayor viene recogido en las Partidas, II, 9, 17 y II, 13, 2 .

${ }^{9} \mathrm{P}$. LóPEZ DE AYALA, Crónica del rey don Juan, primero de Castilla, Crónicas de los Reyes de Castilla, II, Madrid, BAE, LXVIII, 1953, año 1391, caps. XXVII y XXIX, pp. 749 y 751. Juan Hurtado de Mendoza era también "tutor e guarda del rey", ibídem, p. 753, cap. XXX. 
que, "fallesciendo Juan Furtado de Mendoza, nuestro alférez mayor, sea en su lugar Pero González de Mendoza, nuestro mayordomo mayor".

El monarca ordenó que la copa del infante Enrique "la aya Álvaro de Albornoz", y que el dicho Juan Hurtado, su Alférez mayor, "sea siempre en su servicio e crianza". Tras la contienda por la muerte de Pedro González de Mendoza, el rey dio el mayordomazgo a su hijo Diego Hurtado de Mendoza y el del infante don Enrique a Juan Hurtado de Mendoza. En este mismo año hubo una porfía por el mayordomazgo: Juan Hurtado decía que era mayordomo del rey don Juan "e que non dejaría el dicho oficio si no fuese declarado que todos los que tenían oficios del rey don Juan non los oviesen agora". En las Cortes de Madrid se estipuló que mantuviera su oficio y Pedro González de Mendoza fuera guarda del rey, además de solicitar el almirantazgo. Poco después, el alcázar de Segovia quedó custodiado por Juan Hurtado de Mendoza, y en 1393 quedó decidido que éste y los demás tutores gobernaran el reino hasta los catorce años, con los procuradores de las ciudades que estaban con el rey ${ }^{10}$.

\section{El Guarda mayor y los guardas reales}

El Guarda mayor del cuerpo del rey era el encargado de la protección personal del monarca, aunque los orígenes y connotaciones del cargo son confusos, ya que su función se solapa con la del Alférez mayor. Sus cometidos eran la jefatura superior de la guardia real, la supervisión de la organización de la vigilancia y de la protección del cuerpo del monarca y el apoyo a actividades de orden público dentro de la Corte, a las órdenes del Justicia o Alguacil mayor. Las primeras menciones del oficio datan de finales del siglo XIII y desde entonces diversos personajes nobiliarios se sucedieron en él, como Pedro González de Mendoza en la segunda mitad del siglo XIV. A partir de 1370 el oficio recayó sucesivamente en Fernán Sánchez de Tovar, su hijo Sancho y su nieto Juan de Tovar. Durante el reinado de Juan II varias personas desempeñaron simultáneamente el oficio de Guarda mayor, lo que podía obedecer a su función efectiva por turnos ${ }^{11}$.

Este cargo fue ocupado por numerosos nobles de origen conquense en los reinados de Juan II y Enrique IV, entre ellos Pedro de Acuña y Albornoz, conde de Buendía y señor de Dueñas ${ }^{12}$ e integrante del Consejo Real, y retribuido con una quitación anual de 20.000 mrs. Además de este salario, los

\footnotetext{
${ }^{10}$ Ibídem, año 1392, cap. VI, pp. 767, 770, 777 y 785; cap. VIII, p. 786; cap IX, p. 788; cap. $X$, p. 789; año 1393, cap. ${ }_{\text {, p. }}$ 805. El duque de Benavente tomó a un hijo de Juan Hurtado de Mendoza como rehén, ano 1393, cap. XII, p. 820; año 1394, cap. IV, p. 843 y cap. VI, p. 846.

${ }^{11} \mathrm{~J}$. de SAlAZAR Y ACHA, La Casa del Rey de Castilla y León en la Edad Media, ob. cit., pp. 324-326. En 1447 constan asentados en los libros Juan de Tovar, Iñigo Ortiz de Estúñiga, Juan Pacheco, Juan de Luna, Pedro Alvarez de Osorio y Pedro de Acuña, quienes, además, habían hecho hereditario el cargo en sus familias.

${ }^{12}$ Sobre el linaje Acuña, además de la bibliografía citada en la nota 6, destacamos nuestro trabajo Notas sobre los señoríos palentinos de los Acuña, condes de Buendia, a finales de la Edad Media, "Publicaciones de la Institución Tello Téllez de Meneses", en prensa.
} 


\section{oficios solían ser remunerados con rentas "situadas" sobre los impuestos del reino castellano, en tierras de los obispados de Cuenca y Palencia:}

Pedro de Acuña, guarda mayor del Rey. Mandóle el Rey librar en quitaçión cada año con el dicho ofiçio por su alualá firmado de su nonbre el año que pasó de IU ccccxxxvi años e dende en adelante en cada año xx U, segúnd que los tenía de quitaçión cada año cada uno de los otros sus guardas mayores, en esta guisa: $\mathrm{x}$ de los xl U que Ferrand Péres de Ayala tenía por merçed en cada año, por quanto es finado, e los otros $\mathrm{x} \mathrm{U}^{13}$.

\section{El oficio lo traspasó en 1465 a su hijo Lope Vázquez de Acuña, Adelantado de Cazorla:}

Yo el Rey fago saber a vos, los mis contadores mayores, que mi merçed e voluntad es que los veinte mill mrs. que don Pedro de Acuña, conde de Buendía, mi guarda mayor e del mi Consejo, tiene de mí en quitaçión cada año con el dicho ofiçio de mi guarda mayor, los aya e tenga de mí don Lope Vásques de Acuña, adelantado de Caçorla, su fijo mayor legítimo ${ }^{14}$.

Lope Vázquez de Acuña, a su vez, hizo lo propio con su hijo Juan de Acuña en 1489 , con una ración y quitación anual de $20.000 \mathrm{mrs} .{ }^{15}$.

${ }^{13} \mathrm{~A}$ (rchivo) G(eneral) (de) S(imancas), Q(uitaciones) (de) C(orte), leg. 4, fol. 427.

En 1456 Pedro de Acuña distribuyó asî los 26.000 mrs. de sus oficios de Guarda mayor y oficial del cuchillo: $6.000 \mathrm{mrs}$. del reppartimiento de los señoríos del obispado de Jaén le fueron librados "en las villas e lugares que tiene en el adelantamiento" y $19.000 \mathrm{mrs}$. del repartimiento de los señoríos de la merindad de Campos con Palencia le libraron "sennaladamente en la su villa de Dueñas", Palencia, 20 diciembre 1456, AGS, QC, leg. 4, fol. 181r.

En 1457'le fueron librados $4.000 \mathrm{mrs}$. del repartimiento de los señoríos del partido de Huete "en la su villa de Buendía", 16.000 mrs. del repartimiento de los señoríos de la merindad de Campos con Palencia en Dueñas y 5.000 mrs. del repartimiento de los señoríos del obispado de Jaén "en las villas e lugares del adelantamiento de Caçorla", Madrid, 20 noviembre 1457, AGS, $\mathrm{QC}$, ibidem.

En 1458 le fueron librados en su villa de Dueñas $6.000 \mathrm{mrs}$. del repartimiento de los señoríos de la merindad de Campos con Palencia, $10.000 \mathrm{mrs}$. del repartimiento de los señoríos de Campos y $10.000 \mathrm{mrs}$. en el repartimiento de los señoríos de las tercias del adelantamiento, Medina del Campo, 25 enero 1459, AGS, QC, leg. 4, fol. 181v.

En 1459 le fueron librados 3.000 mrs. del repartimiento de los señoríos del obispado de Jaén en las villas y lugares del adelantamiento de Cazorla, $3.000 \mathrm{mrs}$. del repartimiento de la merindad de Cerrato "en su lugar de Cubillas de Çerrato" y $20.000 \mathrm{mrs}$. del repartimiento de los señoríos de la merindad de Campos con Palenciả en las alcabalas de Dueñas, 28 noviembre 1459, AGS, QC, ibidem.

En 1461 le fueron librados $10.000 \mathrm{mrs}$. en el repartimiento de los señoríos de las tercias del adelantamiento en su villa de Dueñas, $6.000 \mathrm{mrs}$. del repartimiento de los señoríos de la merindad de Campos con Palencia en su villa de Dueñas y $10.000 \mathrm{mrs}$. del repartimiento de la merindad de Campos en :?, Madrid, 20 febrero 1461, AGS, OC, leg. 4 , fol. $182 \mathrm{r}$.

En 1462 le fueron librados $10.000 \mathrm{mrs}$. en el repartimiento de los señoríos de la merindad de Campos con Palencia en su villa de Dueñas, $10.000 \mathrm{mrs}$. del repartimiento de las tercias del adelantamiento en su villa de Dueñas y $6.000 \mathrm{mrs}$. del repartimiento de los señoríos del partido de Huete en su villa de Buendía, Madrid, 20 diciembre 1464, AGS, QC, leg. 4, fol. 182v.

En 1463 le fueron librados 10.000 mrs. en el repartimiento de los señoríos de la merindad de Campos con Palencia en su villa de Dueñas, $10.000 \mathrm{mrs}$. del repartimiento de los señoríos de las tercias del adelantamiento en su villa de Dueñas y $6.000 \mathrm{mrs}$. del repartimiento de los señoríos del partido de Huete en su villa de Buendía, Madrid, 20 agosto 1464, AGS, QC, ibidem.

${ }^{14} 28$ octubre 1465, AGS, QC, leg. 4, fols. 41r-42r. En 1294 Sancho Sánchez, Guarda mayor de Sancho IV, cobraba una quitación de 3.600 mrs., J. de SALAZAR Y ACHA, ob. cit., p. 326.

${ }^{15} 26$ marzo 1489, R(eal) A(cademia) (de la) H(istoria), Salazar y Castro, D-13, fol. 50r-v. Lope Vázquez de Acuña tenia asentada esa cantidad el 23 de julio de 1481; dos días antes aparece en la documentación que tenía $14.400 \mathrm{mrs}$. de ración como Guarda mayor. 


\section{Cuadro 1. Distribución de los mrs. que Pedro de Acuña obtenía por sus oficios de Guarda mayor y oficial del cuchillo (1456-1463)}

\begin{tabular}{|c|c|c|}
\hline AÑO & LUGARES & CANTIDAD \\
\hline \multirow[t]{2}{*}{1456} & $\begin{array}{l}\text { Adelantamiento de Cazorla (repartımiento de } \\
\text { los señoríos del obispado de Jaén). }\end{array}$ & $6.000 \mathrm{mrs}$. \\
\hline & $\begin{array}{l}\text { Dueñas (repartimiento de los señoríos de la } \\
\text { merindad de Campos con Palencia). }\end{array}$ & $19.000 \mathrm{mrs}$. \\
\hline \multirow[t]{3}{*}{1457} & $\begin{array}{l}\text { Buendía (repartimiento de los señoríos del } \\
\text { partido de Huete). }\end{array}$ & $4.000 \mathrm{mrs}$. \\
\hline & $\begin{array}{l}\text { Dueñas (repartimiento de los señoríos de la } \\
\text { merindad de Campos con Palencia). }\end{array}$ & $16.000 \mathrm{mrs}$. \\
\hline & $\begin{array}{l}\text { Adelantamiento de Cazorla (repartımiento de } \\
\text { los señoríos del obispado de Jaén). }\end{array}$ & $5.000 \mathrm{mrs}$. \\
\hline \multirow[t]{3}{*}{1458} & $\begin{array}{l}\text { Dueñas (repartimiento de los señoríos de la } \\
\text { merindad de Campos con Palencia). }\end{array}$ & $6.000 \mathrm{mrs}$. \\
\hline & Repartimiento de los señoríos de Campos. & $10.000 \mathrm{mrs}$. \\
\hline & $\begin{array}{l}\text { Tercias del adelantamiento de Cazorla (reparti- } \\
\text { miento de los señoríos). }\end{array}$ & $10.000 \mathrm{mrs}$. \\
\hline \multirow[t]{3}{*}{1459} & $\begin{array}{l}\text { Adelantamiento de Cazorla (repartımiento de } \\
\text { los señoríos del obispado de Jaén). }\end{array}$ & $3.000 \mathrm{mrs}$. \\
\hline & $\begin{array}{l}\text { Cubillas de Cerrato (repartimiento de la me- } \\
\text { rindad de Cerrato). }\end{array}$ & $3.000 \mathrm{mrs}$. \\
\hline & $\begin{array}{l}\text { Alcabalas de Dueñas (repartimiento de los } \\
\text { señoríos de la merindad de Campos con Palen- } \\
\text { cia). }\end{array}$ & $20.000 \mathrm{mrs}$. \\
\hline \multirow[t]{3}{*}{1461} & $\begin{array}{l}\text { Dueñas (repartımiento de los señoríos de las } \\
\text { tercias del adelantamiento). }\end{array}$ & $10.000 \mathrm{mrs}$. \\
\hline & $\begin{array}{l}\text { Dueñas (repartimiento de los señoríos de la } \\
\text { merindad de Campos con Palencia). }\end{array}$ & $6.000 \mathrm{mrs}$. \\
\hline & Repartımiento de la merindad de Campos & $10.000 \mathrm{mrs}$ \\
\hline \multirow[t]{3}{*}{1462} & $\begin{array}{l}\text { Duenas (repartımiento de los senorios de la } \\
\text { merindad de Campos con Palencia). }\end{array}$ & $10.000 \mathrm{mrs}$. \\
\hline & $\begin{array}{l}\text { Dueñas (repartimiewnto de las tercias del ade- } \\
\text { lantamiento). }\end{array}$ & $10.000 \mathrm{mrs}$ \\
\hline & $\begin{array}{l}\text { Buendia (repartimiento de los señorios del } \\
\text { partido de Huete). }\end{array}$ & $6.000 \mathrm{mrs}$. \\
\hline \multirow[t]{3}{*}{1463} & $\begin{array}{l}\text { Dueñas (repartimiento de los señoríos de la } \\
\text { merindad de Campos con Palencia). }\end{array}$ & $10.000 \mathrm{mrs}$. \\
\hline & $\begin{array}{l}\text { Duenas (repartimiento de los senorios de las } \\
\text { tercias del adelantamiento). }\end{array}$ & $10.000 \mathrm{mrs}$. \\
\hline & $\begin{array}{l}\text { Buendia (repartimiento de los señoríos del } \\
\text { partido de Huete). }\end{array}$ & $6.000 \mathrm{mrs}$ \\
\hline
\end{tabular}

Otros nobles de procedencia conquense fueron guardas del rey, como Pedro Vázquez de Acuña o Juan de Cabrera, que cobraban una quitación de 
3.000 mrs. ${ }^{16}$. El propio Pedro Vázquez de Acuña figuraba en los libros de los contadores reales entre los años 1455-1459 y 1461-1463 ${ }^{17}$. Los guardas eran hombres armados y montados a la brida, con el caballo encubertado. La guarda del rey se componía de doce individuos en tiempos de Sancho IV. Durante la minoría de Alfonso XI las Cortes encomendaron su guarda a veinticuatro caballeros, que eran escogidos en grupos de seis por regiones - Castilla, León, Extremadura y Andalucía - y hacían servicio en grupos de ocho cada cuatro meses. En el reinado de Enrique III la guarda real estaba formada por tres capitanías con cien lanzas cada una, y alcanzaron el número total de mil lanzas en época de Juan II, por lo que las Cortes negociaron su reducción hasta cien. A mediados del siglo XV la documentación especifica que los guardas constituían un número fijo, cuarenta en 1447 y sesenta en $1448^{18}$; podemos suponer que la cifra restante hasta alcanzar las cien lanzas era ocupada por diversos grupos de escuderos, ballesteros y Monteros de Espinosa, que también velaron por la seguridad del monarca a lo largo de la baja Edad Media.

\section{El Ballestero mayor}

Los ballesteros eran oficiales de la guarda del rey que estaban a las órdenes de un Ballestero mayor, que era un oficial auxiliar encargado de cumplir las funciones abandonadas por los oficiales mayores tradicionales. El uso de la ballesta fue popularizada en Europa durante el siglo XII. En época de Sancho IV existía un Ballestero mayor o Mayoral de los ballesteros, Fernán Yáñez. En el siglo XIII existían 60 ballesteros, que asumieron también funciones policiales a las órdenes del Alguacil mayor. En el siglo XIV surgieron los ballesteros de maza, que pertenecían al círculo más cercano del monarca y desarrollaban funciones similares.

Durante el reinado de Alfonso XI conocemos al Ballestero mayor Sancho Sánchez de Rojas; con Pedro I fueron ballesteros mayores Martín Díaz de Albarracín, Pedro López de Padilla y el tártaro Zorzo; Enrique II nombró a Juan de Avendaño, cuyos sucesores fueron obteniendo el oficio por confirmación real. También consta el noble conquense Fernán Carrillo, señor

\footnotetext{
${ }^{16}$ Pedro Vázquez de Acuña, hijo del mencionado Pedro de Acuña, obtuvo $3.000 \mathrm{mrs}$. de quitación como guarda del rey en 1447, en lugar de Gonzalo Docales, que había fallecido, AGS QC, leg. 4, fol. 238. Juan de Cabrera recibio dos décadas después 10.200 mrs., 3 noviembre 1465, AGS, QCं, leg. 3, fol. 477.

${ }^{17}$ "Pedro Vásques de Acuña, fijo de Pedro de Acuña, guarda del Rey. Tiene del Rey en quitación cada año con el dicho ofiçio iii U, segúnd más largamente se contiene en el año de iU cccc lv años", AGS, QC, leg. 4, fól. 453.

En 1456 y 1457 a Pedro Vạquez de Acuña le fueron librados los 3.000 mrs. de su oficio de guarda del Rey del repartimiento de los señoríos del partido de Atienza en la villa de Berlanga, Palencia, 20 diciembre 1456 y Madrid, 3 diciembre 1457, AGS, QC, ibídem. En 1458, 1459 1461,1462 y 1463 le fueron librados los $3.000 \mathrm{mrs}$. del repartimiento de los señoríos del obispado de Jaén en el adelantamiento de Cazorla, Madrid, 25 enero 1459, Madrid, 28 septiembre 1459, Madrid, 20 diciembre 1460, Madrid, 21 mayo 1463 y Madrid, 11 mayo 1464, AGS, QC, ibídem.
}

${ }^{18}$ J. de SAlAZAR Y ACHA, ob. cit., pp. 326-328. 
de Priego, como Ballestero mayor de Juan I entre 1380 y 1382. El Ballestero mayor cobraba 12.000 mrs. de quitación ${ }^{19}$.

\section{El Montero mayor ${ }^{20}$}

La afición cinegética de los reyes castellanos medievales hacía necesaria la participación de numerosos elementos auxiliares, cuyas funciones se hicieron paulatinamente permanentes y llegaron a rebasar estrictamente el ámbito de las prácticas venatorias. Los monteros fueron oficiales de la Casa real que desempeñaron no sólo tareas de apoyo en las cacerías reales, sino también en la administración ${ }^{21}$. La montería era propiamente la caza de jabalíes, ciervos y osos, aunque el vocablo venado englobaba universalmente a los tres ${ }^{22}$. Durante el siglo XV el Montero mayor fue en Castilla uno de los dignatarios de mayor consideración de la corte; al frente de otros monteros, junto al Halconero mayor, debía dirigir las batidas cuando los reyes practicaban la caza, distribuyendo los grupos de cazadores por el monte bajo ${ }^{23}$.

$\mathrm{Su}$ origen castellano se remonta al reinado de Alfonso VIII, que concedió a los monteros del solar de Espinosa exención tributaria y hereditariedad del cargo, debiendo acudir a la corte cuando el monarca les requiriera. Este tratamiento de favor hace suponer que los monteros de Espinosa prestaran servicios de naturaleza distinta a la cinegética. Efectivamente, en el reinado de Alfonso X los monteros de Espinosa aparecen desempeñando funciones administrativas de cierto relieve, como oficiales de justicia o militares; tal vez, entre sus funciones judiciales estaban los prendimientos o ejecuciones por orden del rey. Por lo tanto, desde mediados del siglo XIII se distinguen los

\footnotetext{
${ }^{19}$ Ibídem, pp. 333-336 y 565.

${ }^{20}$ Este apartado ha sido publicado, con un contenido más pormenorizado, en nuestro trabajo La funcionalidad política de la nobleza castellana: el oficio de Montero mayor durante el siglo $X V$, "Historia. Instituciones. Documentos", 30 (2003), pp. 419-448.

${ }^{21} \mathrm{D}$. TORRES SANZ, La administración central castellana en la Baja Edad Media, Valladolid, 1982, p. 273.

${ }^{22}$ J. VALLÉs, Libro de la montería, F. Osuna Lucena (ed.), Universidad de Córdoba, 1995, cap. I, p. 63. Esta obra de 1556 se basa para su elaboración en el tratado de Alfonso Xİ, cuyo Libro de la Montería es una auténtica guía de la práctica cinegética: equipación, cuándo ir a correr el monte, crianza y cuidado de los canes, etc. El libro tercero ofrece una detallada descripción geográfica de los montes de Castilla y León. Existen varias ediciones de la obra: J. GUTIERREZ DE LA VEGA, Libro de la Montería del Rey Alfonso XI, Biblioteca Venatoria, t. I y II, Madrid, 1877 (int. J.E. Casariego, ed. Madrid, 1976); G. ARGOTE DE MOLINA, Libro de la Montería que mandó escrevir el Muy Alto y Muy Poderoso Rey Don Alonso de Castilla y de León. último deste nombre, Sevilla, Andrea Pescioni, 1582. Más información sobre el ejercicio de la montería - o caza mayor - en la obra del Duque de ALMAZÁN (A. DE MÁRIÁTEGUI Y PÉREZ DE BARRADAS), Historia de la montería en Espana, Madrid, 1934 (ed. fac-simil 1981).

${ }^{23}$ L. García de VAldeavellano, Curso de Historia de las Instituciones españolas. De los orígenes al final de la Edad Media, Madrid, Alianza, 1968, p. 495.
} 
monteros de montería y los monteros judiciales y militares ${ }^{24}$. Los monteros también podían cumplir misiones de seguridad además de la suya específica ${ }^{25}$.

Desde la segunda mitad del siglo XIV el linaje Carrillo, señores de Priego, aparecen en el desempeño de este cargo. Así, Fernando Carrillo fue Montero mayor durante los reinados de Enrique II y Juan I, aunque apenas tenemos datos ${ }^{26}$. El linaje Hurtado de Mendoza desempeñó el cargo de Montero mayor sucesivamente durante todo el siglo XV, aunque hubo periodos en los que paralelamente ocuparon el oficio otros personajes. Diego Hurtado de Mendoza fue Montero mayor de Juan II, Juan Hurtado de Mendoza lo fue de Enrique IV y Honorato de Mendoza y Diego Hurtado de Mendoza sirvieron a los Reyes Católicos ${ }^{27}$.

Diego Hurtado de Mendoza, primer señor de Cañete, obtuvo la dignidad de Montero mayor del rey Enrique III en 1406, manteniéndola durante la mayor parte del reinado de Juan II, quien se la confirmó en $1428^{28}$. Diego Hurtado renunció el cargo en su hijo Juan Hurtado de Mendoza, segundo señor de Cañete, en 1437, solicitando al monarca que le mantuviera con el sueldo y la ración y quitación anuales que él cobraba, utilizando para ello súplicas en términos vasalláticos:

El vuestro vmill seruidor de vuestra señoría, Diego Furtado de Mendoça, vuestro montero mayor e del vuestro Consejo, veso vuestras manos e me encomiendo en vuestra merçed, a la qual plega saber que yo, acatando el

${ }^{24}$ D. TORRES SANZ, ob. cit. . pp. 273-275. Sobre un fabuloso origen de los Monteros en tiempos del III conde castellano Ḋon Sancho Fernández, P. DE LA ESCALERA GUEVARA, Origen de los Monteros de Espinosa, Madrid, 1632. Las funciones auxiliares que desarrollaron en materia judicial aparecen descritas en el Ordenamiento de Alcalá, XX, 5 . A fịnes del siglo XV los Monteros de Espinosa desempeñaban funciones domésticas de vigilancia armada de los aposentos reales, G. FERNÁNDEZ DE OvIEDO, Libro de la Cámara Real del Príncipe Don Juan e officios de su casa e seruiçio ordinario, Madrid, Sociedad de Bibliófilos Españoles, 1870, pp. 126-128. Esta obra del primer tercio del siglo XVI describe detalladamente las tareas de todos los oficiales que estaban al servicio de la Corte regia.

Durante el reinado de Isabel I, efectivamente, los Monteros de Espinosa se encargaban de la guardia nocturna del palacio. En la casa de la reina había 24 monteros permanentes, pero en 1495 aumentaron a 64 y se modificó su servicio a tiempo parcial, seis meses, distribuidos de la siguiente forma: 36 en la corte, 12 en la casa del rey, 12 en la casa de la reina y 12 en la del príncipe Juan, A. FERNÁNDEZ DE CóRDOVA MIRALLES, ob. cit., pp. 201-203.

${ }^{25}$ M. Á. LAdero QuesAdA, La Casa Real en la Baja Edad Media, ob. cit., p. 337. Los monteros de la guarda aparecen en las cuentas a mediados de la década de 1490', cobrando un buén salario: en 1498 eran 26, pero su número se redujo a 12 en 1504, A. FÉRNÁNDEZ DE CóRDOVA Miralles, ob. cit., p. 195.

${ }^{26}$ En 1379 Juan I confirmó un privilegio otorgado por Enrique II en las Cortes de Toro de 1373 a Fernán Carrillo, por el que podía tomar doce monteros de las tierras de Cuenca libres de todo pecho y tributo, A'(rchivo) H(istórico) N(acional), NOBLEZA, Priego, C. P. 53, D. 17, 20 agosto 1379, cit. A. LAFUENTE URIÉN, Inventario del Archivo de Ios Condes de Priego, Salamanca, 1999, p. 55 . Fernán Carrillo era Montero mayor del infante don Juan, al menos desde 1371, ya que, trascurrida la batalla de Nájera, Enrique II le concedió la aldea de Cañaveras, ibidem, C. P. 53, D. 17, 20 septiembre 1371, cit. ibidem, p. 61.

${ }^{27}$ Juan Hurtado de Mendoza fue designado Montero mayor en 1455 por renuncia de su padre, AGS, QC, leg. 1, fol. 434 y AGS, E(scribanía) (Mayor) (de) R(entas), leg. 682, fol. 341, I junio 1453. Los senores de Cañete asumieron el oficio de guarda mayor de la ciùdad de Cuenca durante la mayor parte del siglo XV, J. I. ORTEGA CERVIGÓN, El intrusismo nobiliario en los concejos castellanos: el oficio de guarda mayor de Cuenca durante el siglo XV, en J.F. Jiménez.Alcázar, J. Ortuño Molina y J. A. Eiroa Rodríguez (eds.), "Actas I Simposio de Jóvenes Medievalistas Lorca 2002", Murcia, 2003, pp. 147-162.

${ }^{28}$ Segovia, 28 enero 1428, AGS, QC, leg. 4, fols. 648r-650v. 
grand debdo que con Juan Furtado de Mendoça, mi fijo mayor legítimo, conmigo tyene, e asy mesmo, entendiendo que es tal persona que guardará lo que cunple a vuestro seruiçio, e yo querría e quiero, e por la presente renunçio e traspaso en el dicho ofiçio de montería mayor que de vuestra altesa tengo, con los marauedís e raçión e quitaçión que yo he de vuestra altesa con el dicho ofiçio. Por merçed, muy poderoso Rey e señor, omillmente suplico a vuestra señoría que acatando los dichos buenos e leales seruiçios que aquellos onde yo vengo fesieron a los reyes de gloriosa memoria, vuestros progenitores, e asy mesmo ellos e yo avemos fecho e fasemos de cada día a vuestra altesa, que vuestra señoría faga merçed al dicho Juan Furtado de Mendoça, mi fijo, del dicho ofiçio de montero mayor, e le mande poner e asentar en vuestros libros ${ }^{29}$.

\section{El rey Juan II confirmó el traspaso del oficio por renuncia de Diego Hurtado unos días después:}

se testó e quitó de los dichos libros al dicho Diego Furtado el dicho ofiçio de montero mayor e se puso e asentó en su lugar el dicho Iohan Furtado de Mendoça, su fijo, para que sea montero mayor del dicho señor Rey de los dichos dosientos e seys monteros, segúnd e en la manera quel dicho Diego Furtado, su padre, lo era [...]. Por faser bien e merçed a vos, Iohan Furtado de Mendoça, fijo mayor legítimo de Diego Furtado de Mendoça, mi montero mayor e del mi Consejo, por los buenos e leales seruiçios quel dicho Diego Furtado de Mendoça, vuestro padre, me ha fecho e fase de cada día, tengo por bien e es mi merçed que agora e de aquí adelante, para en toda vuestra vida, seades mi montero mayor en lugar del dicho Diego Furtado de Mendoça, vuestro padre, [...] segúnd e por la forma e manera e con las mesmas prerrogatiuas quel dicho vuestro padre de mí lo tenía ${ }^{30}$.

La confirmación de la merced de montería también viene recogida en otro documento:

Renunçió el dicho Diego Furtado este ofiçio de montería en Juan Furtado de Mendoça, su fijo, al qual el Rey fiso merçed del por su carta firmada de su nonbre, e asentóse adelante la dicha carta de renunçiaçión con vna çédula del Rey en el mes de mayo del año de mill e quatroçientos e çinquenta e tres años, mayo $1453^{31}$.

No obstante, hasta 1453 no se hizo efectiva la merced porque los contadores reales no podían asentar ninguna merced en sus libros sin el "espeçial mandado" del rey y "desde dicho tiempo acá" nunca les trajeron dicha merced ni les requirieron para que la asentaran.

En ocasiones la documentación distingue un Montero mayor del rey y un Montero mayor del príncipe, pero otras veces dos personas aparecen con

\footnotetext{
${ }^{29}$ Cañete, 20 junio 1437, AGS, EMR, leg. 682, fol. 341, fols. 1v-2r.

${ }^{30}$ Medina del Campo, 30 agosto 1437, AGS, EMR, leg. 682, doc. 341, fols. 1r-2r. El traslado de esta carta se hizo en Torrijos, el 28 de mayo de 1453 , cuatro días después de que Juan II volviera a mandar a sus contadores que asentaran en sus libros a Juan Hurtado de Mendoza como Montero mayor. La confirmación de la merced de montería también viene recogida en otro documento:

${ }^{3}$ AGS, QC, leg. 4, fol. 648r.
} 
el mismo título del oficio, aunque tal vez no lo desempeñaron simultáneamente. En 1445 el príncipe Enrique tomó como Montero mayor a Esteban Pacheco, gracias a una merced que Juan II le había hecho de los monteros del rey de Navarra. Esteban Pacheco aparece mencionado en la documentación con el mismo título, al menos, hasta 1460, y también se debió ocupar de los monteros de Enrique IV una vez coronado rey. A la muerte de Esteban Pacheco, desempeñaron el oficio Gonzalo de Ledesma y su hijo Pedro de Ledesma $^{32}$. Los Reyes Católicos otorgaron simultáneamente en 1475 a Honorato de Mendoza "merçed que para en toda su vida sea montero mayor con quitación" y a Diego de Valderrábano, que ya lo disfrutaba desde 1461, por lo que parece que hubo varios monteros mayores hasta la prematura muerte de Honorato en 1489 durante la guerra de Granada ${ }^{33}$. Entre 1477 y 1498 también aparece otro personaje con la condición de Montero mayor, mosén Lope de Ataguía, comendador de Malagón ${ }^{34}$. Diego Hurtado de Mendoza recibió la merced del oficio en 1499:

Don Fernando por la graçia de Dios, por faser bien e merçed a vos Dyego Furtado de Mendoça, hijo de Honorato de Mendoça, tengo por bien e es mi merçed que agora e de aquí adelante para en toda vuestra vida seades nuestro montero mayor sobre todos los otros nuestros monteros ${ }^{35}$.

Las facultades del Montero mayor eran el mando y nombramiento de los monteros de montería y, presumiblemente, la jefatura - directa o delegada - de todos los demás monteros. También se ocupaba de la preparación de redes y otros aparejos precisos para las cacerías, como hacía Diego de Valderrábano en el reinado de Enrique IV, incluso sabemos que el Montero mayor servía con dos lanzas ${ }^{36}$. Apenas existen referencias sobre el oficio hasta el siglo XV, momento en que los monteros mayores estaban perfectamente individualizados como miembros de la alta nobleza que ostentaban su titularidad con carácter honorífico. Según algunos cronistas de la época el oficio tenía cierto prestigio social, al tener a su disposición

todos los otros monteros de tal exerçiçio, en el qual ay tantos e tales e con tanto gusto, quanto es la voluntad rreal de aumentar monteros e canes e lebreles e sabuesos e ventores e vallesteros e otras cosas, que tocan al hilo

\footnotetext{
${ }^{32} \mathrm{~J}$. de SALAZAR Y ACHA recoge una quitación de corte de 1460 en la que aparece Esteban Pacheco como Montero mayor de Enrique IV, ob. cit., p. 539. Gonzalo de Ledesma fue Montero mayor desde el 13 de febrero de 1460 y su hijo Pedro de Ledesma figura aún como tal el 4 de agosto de 1462, AGS, QC, leg. 3, fols. 362-365 y leg. 4, fol. 327, cit. ibídem, p. 539.

${ }^{33} \mathrm{AGS}$, R(egistro) G(eneral) (del) S(ello), 4 febrero 1475, fols. 128 y 129 y 10 marzo 1475 , fol. 253; ÂGS, EMR, leg. 682, fol. 248, 6 abril 1478.

${ }^{34}$ AGS, EMR, leg. 682 fol. 247, 15 abril 1477; AGS, RGS, 24 septiembre 1485, fol. 165; ibídem, 27 agosto 1486 , fol. 4 ; ibidem, 18 agosto 1491, fol. 139; ibídem, 6 abril 1498, fol. 25 .

${ }^{35}$ AGS, RGS, 25 marzo 1499, fol. 417.

${ }^{36} \mathrm{M}$. Á. LADERO QUeSADA, 1462: un año en la vida de Enrique IV, rey de Castilla, "En la España Medieval”, 14 (1991), pp. 255 y 271.
} 
con que çercan el monte para los oxeos y matar las saluaginas, de qualquier genero o calidad que sean y subçedan en la monteria ${ }^{37}$.

El Montero mayor - junto al Cazador mayor y al Halconero mayordependía del Camarero mayor, por lo que estaba muy vinculado con la Casa Real. Respecto a su salario, sabemos que Diego Hurtado de Mendoza, Montero mayor en tiempos de Juan II, recibió una merced de $20.000 \mathrm{mrs}$. cuando el rey salió de Aragón en $1429^{38}$. Juan Hurtado de Mendoza cobraba 8.000 mrs. de quitación anual durante el reinado de Enrique IV $^{39}$, que no era una cantidad muy elevada si se compara con lo que recibían otros oficios

\section{Cuadro 2. Monteros mayores de Castilla durante la baja Edad Media ${ }^{40}$}

\begin{tabular}{|c|c|}
\hline REINADO & MONTEROS \\
\hline Sancho IV & Martín Ruiz ( $\mathrm{ca} .1294)$ \\
\hline \begin{tabular}{|l|l} 
Alfonso XI \\
\end{tabular} & Diego Bravo (ca. 1350) \\
\hline Pedro 1 & Lope González de Valderrábano (ca. 1360) \\
\hline \multirow[t]{2}{*}{\begin{tabular}{|l|l|} 
Enrique II \\
\end{tabular}} & Fernán Carrillo ( $\mathrm{ca} .1373-1390)$ \\
\hline & Rodrigo Álvarez Osorio ( $\mathrm{ca} .1375$ ) \\
\hline \begin{tabular}{|l|l|l|l} 
Juan 1 \\
\end{tabular} & Pedro González de Valderrábano (ca. 1384) \\
\hline Enrique III & Ruy Díaz de Mendoza ( $c a .1390-1406)$ \\
\hline \multirow{2}{*}{ Juan II } & Diego Hurtado de Mendoza (1406-1437) \\
\hline & Juan Hurtado de Mendoza (1437-1455) \\
\hline \multirow[t]{4}{*}{ Enrique IV } & Esteban Pacheco (1455-1460) \\
\hline & Gonzalo de Ledesma (1460) \\
\hline & Pedro de Ledesma (1460-1462) \\
\hline & Diego de Valderrábano ( $c a .1461-1475)$ \\
\hline \multirow[t]{3}{*}{\begin{tabular}{|l|l|l|c|} 
RR. Católicos \\
\end{tabular}} & Honorato de Mendoza (1475-1489) \\
\hline & Lope de Ataguía (1477-1498) \\
\hline & Diego Hurtado de Mendoza (1499-1542) \\
\hline
\end{tabular}

${ }^{37}$ G. FERNÁNDEZ DE OVIEDO, ob. cit., p. 110. Este cronista de comienzos del siglo XVI comenta que el oficio de Montero mayor "era muy honroso y de gran salario".

${ }^{38}$ AGS, EMR, leg. 1, fol. 82, cit. M. Á. LADERO QUESADA, La Hacienda Real de Castilla en el siglo XV, Universidad de La Laguna, 1973, p. 272. L. SUÁREZ FERNÁNDEZ menciona que Diego Hurtado de Mendoza y su mujer cobraron 87.525 mrs. durante 1447, cantidad tenida por salvado, mantenimiento, tierra, quitación, ración, juro, ayuda de costa y otros conceptos, aunque no especifica si era este mismo Montero mayor o el hijo de Iñigo López, marqués de Santillana, AGS, Mercedes y Privilegios, leg. 1, fols. 30-100, Un libro de asientos de Juan II, "Hispania", XVII/68 (1957), pp. 323-368.

39 “Iohan Furtado de Mendoça, montero mayor del Rey, fijọ de Diego Furtado. Tiene del Rey en quitaçión cada anno, con el dicho ofiçio de montero, viii mill mrs. segund mas largo se contiene en el año de miiiilv años", AGS, QC, leg. 3, fol. 516, leg. 4, fol. 648.

${ }^{40}$ J.I. ORTEGA CERVIGÓN, La funcionalidad política de la nobleza castellana: el oficio de Montero mayor durante el siglo XV, ob cit., p. 404. Esteban Pacheco obtuvo la merced de Montero mayor del príncipe Enrique en 1445,' tras cuya coronación suponemos que continuaría desarrollando su labor. Honorato de Mendoza fallecio en 1489 en la lucha contra los nazaríes, aunque no podemos constatar documentalmente si desempeñó el oficio hasta esa fecha. 
cortesanos. En 1462 encontramos un testimonio en el que Gonzalo de Ledesma, Montero mayor de Enrique IV, "tenía en esta guisa de raçión cada día con el dicho ofiçio treinta mrs., que le montan al año diez mill e ochoçientos mrs., e de quitaçión cada año con el dicho ofiçio seys mill mrs., e de casa por un oso nueve cientos mrs." que sumaban una cantidad de 17.700 mrs. ${ }^{41}$. Al comienzo del reinado de Isabel la documentación menciona que el Montero mayor recibía anualmente $6.120 \mathrm{mrs}$. de ración y $23.880 \mathrm{mrs}$. de quitación $^{42}$, cantidad más elevada que en los años precedentes.

Entre las funciones del Montero mayor se incluía la de realizar una nómina de los doscientos seis monteros regios, a quienes debía elegir y sustituir en caso de fallecimiento. También tenía la potestad de privar del oficio a aquellos que no lo desempeñaran correctamente. Los monteros eran designados por zonas geográficas delimitadas por la extensión de los obispados y recibían un albalá o una cédula firmados personalmente por el Montero mayor $^{43}$. A veces, encontramos quejas en las Cortes sobre la selección de un número excesivo de monteros - eran doscientos seis anuales, "francos e quitos de monedas e pedidos e de otros pechos"- entre los pecheros y en algunos lugares alejados de las sierras donde había venados. Esto provocaba cargas fiscales adicionales a los vecinos de las poblaciones donde eran escogidos. Por ejemplo, en las de 1433 el monarca mandó que los monteros fueran asentados en los libros de cuentas "e que los tales non sean delos pecheros mayores, mas de los menores o poco mas" ${ }^{\prime 4}$. En las Cortes de 1451 los procuradores solicitaron

que los doçientos e seys monteros que de vuestra alteza tiene Diego Furtado se asienten en los vuestros libros e cada vno por su nombre, e los tales monteros sean personas sufiçientes que sepan del ofiçio, e non de los que tratan otros ofiçios asi commo sastres, çapateros e mercaderes e de semejantes ofiçios, e que vuestra alteza mande que vayan nonbrados por sus nonbres los dichos doçientos e seys monteros en las cartas de los rrepartimientos de los pedidos e monedas que se enbian a las dichas çibdades, e villas de vuestros rregnos ${ }^{45}$.

Juan II redujo el número de monteros al servicio de la Casa Real, a petición de los procuradores:

\footnotetext{
${ }^{41} 4$ agosto 1462, AGS, QC, leg. 4, fols. 327-328, publ. J. de SALAZAR Y ACHA, ob. cit., pp. 587-588.

${ }^{42} 10$ marzo 1475, AGS, RGS, fol.253. Diego de Valderrábano, que ya había sido designado Montero mayor un mes antes junto a Honorato de Mendoza, recibió la confirmación de tal favor en un documento fechado en Medina del Campo.

${ }^{43}$ AGS, EMR, leg. 682, fol. 255. Este legajo contiene diversas nóminas, en su mayor parte completas, de los monteros mayores de Juan II y Enrique IV. De Diego Hurtado de Mendoza se conservan nóminas de 1428, 1432, 1437 y 1438.

${ }^{44}$ Cortes de Madrid de 1433 , pet. 15, Cortes de los antiguos Reinos de Castilla y León, Madrid, Real Academia de la Historia, 1866, III, pp. 169-170.

${ }^{45}$ Cortes de Valladolid de 1451, pet. 41, ibídem, p. 629.
} 
Por cuanto el número antiguo de los nuestros escuderos de á pie, ballesteros, y monteros de á caballo es mucho excedido en número, de más y allende de los que solian ser, es nuestra merced de aquí adelante non sean más de veinte y cuatro escuderos de á pie, sesenta ballesteros, veinte y cuatro monteros de á caballo, cuatro monteros de la ventura, cuatro mozos de alanos, y éstos sirviendo gocen ${ }^{46}$.

No obstante, a finales del siglo XV el número parece haberse elevado, pues don Fernando el Católico otorgó a Diego Hurtado de Mendoza "doçientos e çinquenta e seys monteros que vos doy" 47 .

Estos se querellaron en cierta ocasión contra los contadores reales porque no les querían guardar los privilegios y exenciones que tenían de Juan II, quien, en una carta anterior, había mandado "que todos pechen e paguen e non sean escusados personas algunas - saluo de las monedas- los que están puestos por saluados en los mis libros e quadernos dellas". En relación con este asunto, el monarca mandó a sus contadores no empadronar a sus doscientos seis monteros en los pechos reales ni concejiles, "saluo en aquellas cosas en que los priuillegiados e fijosdalgo deuen e son tenudos de contribuyr e pagar segúnd las leyes de los mis regnos" ${ }^{48}$. De esta forma no se quebrantaron los privilegios y franquezas de que disfrutaban los monteros reales.

Las designaciones de los monteros se realizaban con el consentimiento de los poderes concejiles del lugar donde residía el aspirante. Diego Hurtado de Mendoza, a finales del siglo XV, notificó al regimiento y al corregidor de Madrid "commo por una çédula firmada de su nonbre de Diego Hurtado de Mendoça, montero mayor, nonbra por montero en lugar de Juan d'Ávila, defunto, a Juan d'Ávila, su hijo"49. Las sustituciones de unos monteros por otros eran muy habituales, ya que no se realizaban nóminas con una periodicidad fija. Las causas más frecuentes eran el fallecimiento, el cambio de residencia del individuo o la privación del oficio, aunque en la mayor parte de los casos los motivos no se especifican en la documentación ${ }^{50}$. También había ocasiones en las que ellos mismos renunciaban al cargo y eran sustituidos por otra persona en la nómina, como Alfón Gómez de Valdebimbre, hijo de Juan Antúnez, vecino de León, quien sustituyó a Juan Fernández, hijo de Pascual

${ }^{46} \mathrm{G}$. ARGOte de Molina, ob. cit., p. 170.

${ }^{47} 25$ marzo 1499, AGS, RGS, fol. 417.

${ }^{48}$ Segovia, 11 agosto 1439, AGS, EMR, leg. 682, fol. 52. Los monteros decían que "sy asy pasase, ellos resçebirían gran agrauio e daño, e non podrían mantener canes" ni servir al rey "en la dicha montería".

${ }^{49} 12$ abril 1499, Libros de Acuerdos del Concejo Madrileño, C. Rubio Pardos, R. Sánchez González y C. Cayetano Martín (eds.), t. IV (1498-1501), Madrid, 1982, fol. 133r, p. 103.

${ }^{50} \mathrm{El}$ Montero mayor Diego de Valderrábano "toma e nombra por montero del dicho señor Rey en cuenta de los ccvi monteros de la sierra" a Benito Sánchez de la Vaqueriza, hijo de García Fernández de la Vaqueriza, vecino de Madrid, en lugar de Pedro García, hijo de Martín García, vecino de La Cañada del Hoyo. "que fallesçió el día de Sant Juan de iunio del año que pasó de lix," 23 julio 1462, AGS, EMR, leg. 682 fol. 3. También sustituyó a Alfonso Fernandez y Martín Alfonso "en logar e por vacaçión" de Juan Garçía de la Verdeseca, vecino de Escalona, y de Alfonso García Paraíso, vecino de Nombela, "por quanto son finados segúnd paresçió por un testimonio signado de escribano público", 24 mayo 1462 , ibídem. En otra occasion, Diego de Valderrábano nombró por montero del príncipe Âlfonso a Juan de Ortega, vecino de Pinto, "en logar e por priuaçión" de Diego de Orđuña, vecino de Cuenca, 20 enero 1463, ibídem. 
López, vecino de Aravaca, porque "es viejo e tal que non puede seruir el dicho ofiçio e lo renunçió en el dicho Diego Furtado para que lo diese a quien quisiese" 51 .

Gracias a la afición cinegética de Enrique IV, recogida por algunos cronistas y diversos estudios historiográficos, conocemos algunas facetas de la práctica cotidiana de las monterías. Este monarca las realizaba con frecuencia, especialmente en los bosques de Valsaín y El Pardo, donde tenía instaladas reservas campestres cercadas con tapia y edificios en los que descansar de sus cacerías. La guarda de los montes segovianos de Valsaín, su lugar predilecto, estaba encargada a monteros de a caballo, que cobraban entre 450 y 600 mrs. mensuales. Enrique IV realizaba, sin embargo, sus monterías bimensuales en los montes de Robledo, San Martín de Valdeiglesias, Escalona y Adrada, donde habitaban jabalíes, osos, ciervos, cabras monteses y gamos. Las monterías, que duraban habitualmente entre 5 y 10 días, movilizaban a numerosas personas y requerían operaciones previas, como algunas rozas de las comarcas próximas donde se realizaban. Los monteros se contrataban en los pueblos comarcanos y cobraban ocho maravedís diarios ${ }^{52}$.

Los reyes debían contar con hombres de auténtica confianza para realizar las monterías, pues compartían con ellos muchas horas de conversación durante las batidas y cacerías, sobre todo con los monteros y ballesteros. Así, Enrique IV ordenó que fueran francos de pedidos y monedas los monteros que ya nombró en Cuenca siendo príncipe: Fernando de Peñafiel, Diego de la Cueva, Diego de Orduña, Juan de Villarreal, Juan Vázquez, Diego del Castillo, Pedro el Rejero y Alonso de Madrid ${ }^{53}$.

El príncipe Enrique y Juan de Navarra disfrutaron de su propia nómina de monteros - cada una de doscientos- durante el reinado de Juan II de Castilla $^{54}$. En ocasiones algún noble del entorno cortesano también disponía de un número determinado de monteros para realizar sus propias jornadas de cacería. El condestable Álvaro de Luna recibió en 1431 una merced de juro de heredad de Juan II para disponer de veinte monteros "de quales quier que dél tenía el Rey de Nauarra e el ynfante don Enrrique, por quanto los yo priué dellos e de todo lo otro que de mí tenían por çiertas legítimas e sufiçientes cabsas". Álvaro de Luna solicitó tal cantidad de monteros para llevarlos a su villa de Escalona y su tierra, "como en algunos otros lugares de vuestra tierra

\footnotetext{
${ }^{51}$ Cuenca, 28 abril 1458, AGS, EMR, leg. 682, fol. 264.

${ }^{52} \mathrm{M}$. Á. LADERO QUESADA, 1462: un año en la vida de Enrique IV, rey de. Castilla, ob. cit., pp. 252-256. Enrique IV también realizó monterías eventuales en la zona de Agreda, en las que contó con los servicios del Montero mayor de Juan Ramírez de Arellano, señor de Los Cameros, Juan Fonte, así como de otros monteros de aquel noble y de vecinos de la comarca. En 1462 la suma total de gastos por la realización de monterías regias ascendió a $120.000 \mathrm{mrs}$.

${ }^{53} 20$ diciembre 1454, A(rchivo) M(unicipal) (de) C(uenca), leg. 193, exp. 1, fols. 28v-29 cit. C. OLIVERA SERRANO, Inventario de la documentación medieval de las Cortes de Castilla y León en el Archivo Municipal de Cuenca (1250-1500), "En la España Medieval", 19 (1996), doc. 160, p. 383. En las monterías de Enrique IV se contrataban los servicios de entre 200 y 600 campesinos de los pueblos cercanos para obtener mejores resultados al "correr monte", M.A. LADERO QUESADA, La Casa Real en la Baja Edad Media, ob. cit., p. 337.

${ }^{54}$ Existen numerosas nóminas de monteros del rey Juan de Navarra y del príncipe Enrique en AGS, EMR, leg. 682 .
} 
donde ay montes" ${ }^{55}$. Estas personas quedaban exentas del pago de cualquier tipo de tributo y de acudir a las levas militares en los reales o en las fronteras, además de no poder ser detenidas por la justicia de las ciudades o los señoríos.

En 1444, una vez ajusticiado el condestable Álvaro de Luna, el monarca castellano dispuso que los 40 monteros que entonces tenía el maestre de Santiago fueran nombrados por su criado Luis de la Cerda y su concejo, a la que se descontaban 150 mrs. que habría de pagar por cada uno de ellos excusados. Álvaro de Luna tenía un montero salvado en Segovia, 16 en Ávila y 24 en "çiertos partydos de la prouinçia de Andalusya" 56 .

\section{El Halconero mayor}

El Halconero mayor era el encargado de los halcones del rey y su ocupación tuvo gran desarrollo en el siglo XIII por la práctica del deporte de la cetrería entre los grupos privilegiados de la sociedad medieval. Aunque existieron diversos halconeros como oficiales domésticos de la casa del Rey desde el reinado de Alfonso IX de León, hasta 1353 no encontramos la mención de un Halconero mayor, Juan Jofre Tenorio, que era simultáneamente Repostero mayor del Rey Pedro I. Entre 1420 y 1441 desempeñó el oficio Pedro Carrillo de Huete, también conocido por su crónica de Juan II ${ }^{57}$. Después fueron halconeros mayores, durante el reinado de Enrique IV, Miguel Lucas de Iranzo y su sobrino Jaques Lucas, que cobraban una quitación de $10.000 \mathrm{mrs}{ }^{58}$. Entre otros personajes del entorno nobiliario, entre $1455 \mathrm{y}$ 1465 desempeñaba el oficio el segundo conde de Priego, Pedro Carrillo de Mendoza, con una quitación de $4.000 \mathrm{mrs}^{59}$.

El Halconero mayor no tenía derivaciones institucionales, sino que relaizaban diversas funciones cinegéticas. Tenían a su cargo muchos cazadores, catarriberas y mozos de caza, así como una gran variedad de ejemplares de galgos, podencos, aves y halcones.

\section{El Maestresala}

Este oficio tenía a su cuidado los servicios de la mesa del rey, tal vez en calidad de Copero mayor, al que estaban subordinados diversos coperos y

\footnotetext{
${ }^{55}$ Medina del Campo, 26 febrero 1431, ibídem, s. n. Sancho de Escalante, un criado del Condestable Alvaro de Luna, se presentó ante el alcalde de Medina del Campo - "de la tercia poco o más o menos tiempo" - con un albalá firmado por el monarca el 20 de noviembre de 1430 en el que hacía merced de juro de heredad de esos veinte monteros a Alvaro de Luna.

${ }^{56} 18$ enero 1444, ibídem, fol. 279.

${ }^{57}$ Sobre este personaje el profesor J. TORRES FONTES realizó diversas investigaciones, El halconero y los halcones de Juan II, "Murgetana", 15 (1961), pp. 9-20 y Mayorazgo y Testamento de Pedro Carrillo de Huete, halconero real y cronista de Juan II de Castilla. "Anuario de Estudios Medievales", 17 (1987), pp. 437-453.

${ }^{58}$ J. de SALAZAR Y ACHA, ob. cit., pp. 320-322. Miguel Lucas de Iranzo, posteriormente Condestable de Castilla, ejerció el oficio entre 1455 y 1458, 27 diciembre 1458, AGS, QC, leg. 3, fols. 439-440, publ. ibidem, pp. 586-587.

${ }^{59} \mathrm{En} 1455$ cobraba $4.000 \mathrm{mrs}$. como quitación por el oficio, AGS, QC, leg. 4, fol. 244, publ. ibídem, p. 593.
} 
bodegueros $^{60}$. En la Corte también realizaban los servicios de la mesa real los trinchantes, que se encargarían más bien de las viandas. El Maestresala también pudo haber sustituido al oficio de la escudilla, desaparecido a comienzos del siglo XV, al hacerse cargo del comedor. Su cometido era, entre otras funciones, dar las órdenes oportunas para el comienzo de la comida, disponer el orden de los platos y vigilar la calidad y la cantidad de los manjares y del vino. Era el "verdadero maestro de ceremonias del palacio, le estaba encomendado el servicio de la mesa y era el oficio enlace entre la cocina y la mesa regia. Dirigía al cuerpo de pajes y mozos, así como los reposteros de la plata y coperos que estaban a cargo del aparador de la botillería" ${ }^{61}$. Existieron varios maestresalas simultáneamente, porque el oficio era ejercido por turnos de una semana de duración. Parece ser que durante la primera mitad de este siglo fue desempeñado generalmente por hidalgos ${ }^{62}$.

Después sí aparecen personajes de la nobleza conquense, como Andrés de Cabrera, que en 1462, cuando aún era simplemente criado del monarca, obtenía como ración diaria 40 mrs. y como quitación 15.000 mrs., por lo que el montante total ascendía a $29.400 \mathrm{mrs}^{63}{ }^{6}$. Diego Hurtado de Mendoza también fue designado Maestresala por los Reyes Católicos ${ }^{64}$. El salario anual de esta dignidad en 1496 era de 50.000 mrs. ${ }^{65}$.

\section{El oficial del cuchillo}

El oficial del cuchillo o trinchante se encargaba de cortar la carne y la caza que se servía al rey. Estos servidores debían mostrar ciertas cualidades físicas, como la limpieza, la habilidad en el corte. Enrique de Aragón, marqués de Villena, escribió en 1423 el Arte cisoria, un tratado sobre el protocolo a seguir al utilizar el cuchillo ${ }^{66}$. Las primeras referencias del oficio aparecen durante el reinado de Fernando IV, en la persona de Gonzalo Gómez de Calderón. En 1353 servía el cuchillo Suero Pérez de Quiñones, en 1385 Juan Martínez de Medrano y en 1416 Rodrigo Messía sustituyó a su padre

${ }^{60}$ L. García de Valdeavellano, ob. cit., p. 492. En la alta Edad Media este cargo era denominado exclusivamente copero del rey (scanciarius).

${ }^{61}$ Á. FeRnÁNDEZ de CóRdova MiRAlles, ob. cit., p. 142.

${ }^{62} \mathrm{~J}$. de SALAZAR Y ACHA, ob. cit., pp. 284-287. Entre otros, algunos de estos hidalgos maestresalas fueron micer Ventolín, Juan Delgadillo, Alvaro de Luna -cuando era solo un mozo-, Fernán Pérez de Illesceas, Nicolás Fernández de Villamizar, Gonzalo de Castillejo, Pedro de Luzón, mosén Pedro Osorio, Juan de Luján, Diego de Tapia, etc.

63“Yo, el Rey, fago saber a vos, los mis contadores mayores, que mi merced e voluntad es de tomar por mi maestresala a Andrés de Cabrera, mi criado", 10 mayo 1462, AGS, QC, leg. 2 , fols. 241r-242r. Los $29.429 \mathrm{mrs}$. le fueron librados duranté los años de 1462 a 1464 , entre otros, en los repartimientos de las tercias del arzobispado de Sevilla con el de Tuy, de los diezmos y aduanas de los obispados de Cuenca y Cartagena, de los diezmos y monedas del obispado de Osma y Sigüenza y de las alcabalas y tercias de la merindad de Campos con Palencia.

64 “Sepades que Diego Hurtado de Mendoça, nuestro montero mayor, e maestresala e nuestra guarda mayor desa dicha cibdad de Cuenca", AGS, RGS, 25 septiembre 1499 doc 417; "Diego Hurtado de Mendoça, mi maestre sala e montero mayor", AGS, Cámara de Castilla, Personas, 25 febrero 1503, leg. 13.

${ }^{65}$ M.Á. LAdero QueSADA, La Casa Real en la Baja Edad Media, ob. cit., p. 347.

${ }^{66}$ E. DE VILLENA, Arte cisoria, e tratado del arte del cortar del cuchillo, Madrid, 1766. 
Diego González Messía ${ }^{67}$. De los nobles conquenses que ejercieron este cargo figuran Sancho de Jaraba en 1422 y en la década de los cuarenta ${ }^{68}$, Pedro de Acuña ${ }^{69}$, conde de Buendía, en 1427, Gómez Carrillo de Albornoz, señor de Torralba y Beteta, en 1455, su hijo Juan de Albornoz en 1457 y Lope de Acuña en 1466:

Yo el Rey fago saber a vos, los mis contadores mayores, que mi merçed e voluntad es que los seys mill mrs. que de mí auía e tenía Juan de Albornos, fijo de Gómes Carrillo de Albornos, en quitaçión cada año por mi ofiçial del cuchillo asentados en los mis libros, que los aya e tenga de mí en quitaçión cada año con el dicho ofiçio Lope de Acuña, fijo de Lope Vásques de Acuña, mi camarero mayor de las armas, por quanto el dicho Juan de Albornos es finado ${ }^{70}$.

La quitación ascendía a 6.000 mrs. En 1447 eran varios los titulares, quizás al ejercerlo por turnos: Sancho de Rojas, Gómez Carrillo de Albornoz y Pedro de Acuña ${ }^{71}$.

En 1481 Lope Vázquez de Acuña, conde de Buendía y adelantado de Cazorla, tenía 6.000 mrs. por ración y quitación anual, cantidad vigente al traspasar el oficio a su hijo Juan de Acuña ${ }^{72}$.

\section{El Copero mayor}

Durante la alta y plena Edad Media existieron diversos escancianos, coperos y bodegueros encargados del vino y las bodegas del monarca. En el reinado de Alfonso X aparece la primera mención del oficio de Copero mayor, desempeñado por Garci Jofre de Loaysa, con la función de ser el máximo responsable de la mesa del rey, encargándose además de la copa, de la botillería y de la bebida. El oficio se englobaba en el grupo del repostero, despensero y portero, y su quitación anual ascendía a $8.000 \mathrm{mrs}^{73}$.

El linaje Albornoz desempeñó el oficio de Copero mayor durante el siglo XIV. Álvar García de Albornoz lo hizo durante el reinado de Pedro I y

${ }^{67}$ J. de SALAZAR Y ACHA, ob. cit., pp. 282-283.

${ }^{68}$ J.A. JARA FUENTE, "Oue memoria de onbre non es en contrario". Usurpación de tierras y manipulación del pasado en la Castilla urbana del siglo XV "Stvdia Historica. Historia Medieval" (= En memoria de José Luis Martín (1936-2004), 20-21 (2002), nota 35 , p. 87 y
Elites urbanas en Cuenca en la Baja Edad Media. Estructura y procesos internos de diferenciación (siglo XV), en Ir Premio de Investigación Juan Giménez de Aguilar, Cuenca, 1998, nota 74, p. 52 .

${ }^{69} \mathrm{AGS}, \mathrm{QC}$, leg. 4, fols 189 y 427. Pedro de Acuña sustituyó a Pedro de Torres por fallecimiento de éste: "Iohan de Albornos, fijo de Gómes Carrillo de Albornos, allcalde mayor de los fijosdalgo e oficial del cuchillo del Rey [...], tiene más en quitaçión cada año con el dicho ofiçio del cuchillo vi U”.

${ }^{70} 6$ marzo 1466, AGS, QC, leg. 4, fol. 3.

${ }^{71}$ L. SUÁREZ FERNÁNDEZ, Un libro de asientos de Juan II, ob. cit., pp. 342, 348 y 365; AGS, QC, leg. 1, fol. 187 y leg. 4, fol. 181; RAH, Salazar y Castro, M-40, fols. 19-23.

${ }^{72} 26$ marzo 1489, RAH, Salazar y Castro, D-13, fol. 50r-v. Lope Vázquez de Acuña tenía asentadas esas cantidades el 23 de julio de 1481 .

${ }^{73}$ J. de SALAZAR Y ACHA, ob. cit., pp. 278-280. Alonso Enríquez percibió en 146526.400 mrs., aunque esta cantidad incluía quitación y ración. 
su hijo Álvar García el Mozo y su nieto Juan de Albornoz lo fueron bajo Juan $\mathrm{I}^{74}$. Durante el siglo XV el oficio fue patrimonializado por la familia de origen aragonés, los Zapata, aunque otros caballeros desempeñaron simultáneamente el oficio: varios parientes de Álvaro de Luna, como Pedro de Luna en 1446; el primer conde de Alba de Tormes; Alonso Enríquez, hijo del conde de Alba de Lieste; Juan de Haro en $1466^{75}$.

\section{El Camarero mayor de las armas}

El oficio de Camarero mayor, ocupado en el cuidado de la cámara, del lecho y de las vestiduras del monarca, fue desempeñado en la baja Edad Media de forma honorífica por tres oficiales: el Camarero mayor del rey, el Camarero mayor de la cámara de los paños y el Camarero mayor de las $\operatorname{armas}^{76}$. Lope Vázquez de Acuña fue Camarero mayor de las armas de Juan II en 1453 y recibía una quitación de $3.000 \mathrm{mrs}$. anuales ${ }^{77}$. En el documento de concesión de la villa de Huete que le hizo Enrique IV en 1474 aún figuraba como titular del cargo, y aún seis años después ${ }^{78}$.

\section{Los donceles del rey}

Los donceles realizaban durante su infancia funciones domésticas de pajes reales, al servir en la casa del rey, y después realizaban tareas militares. Eran "moços acebtos de los que con él se criaban" y solían adquirir gran confianza con los monarcas, de quienes recibían gran afecto y dádivas.

Andrés de Cabrera era doncel de Enrique IV en 1462 junto a Gonzalo de León y Alonso de Herrera, quienes recibieron un tocado compuesto por un bonete de grana colorada doblados con "carmeñolas", como el mayordomo don Beltrán de la Cueva. Andrés de Cabrera recibió ese año de las cuentas regias un cobro de 48.3000 mrs., 23 varas de terciopelo y 33 de paños, además de los 19.600 mrs. que compartió con Alonso de Herrera para aderezar las fiestas del conde de Armagnac. Durante la enfermedad que padeció en abril, el rey le envió al doctor de Ávila y le entregó 11.2000 mrs.

\footnotetext{
${ }^{74}$ S. de Moxó, Los Albornoz. La elevación de un linaje y su expansión dominical en el siglo XIV, en El Cardenal Albornoz y el Colegio de España, Zaragoza, 1972, I, pp. 37-39. Alvar García de Albornoz ejerció primero el cargo de Copero mayor junto a la reina doña Blanca de Borbón.

${ }^{75}$ J. de SALAZAR Y ACHA, ob. cit., p. 280.

${ }^{76} \mathrm{M}^{\mathrm{a}} \mathrm{J}$. GARCÍA VERA, La nobleza en la sociedad de Corte de Enrique IV, ob. cit., p. 558.

${ }^{77}$ AGS, QC, leg. 4, fol. 239. Lope de Acuña sustituyó a Pedro de Perea, a quien el monarca había privado del oficio "porque estaua contra su deseruiçio en el regno de Nauarra".

${ }^{78}$ Estremera, noviembre 1474, RAH, Salazar y Castro, D-13, fols. 296-297. Carta de "vendida e robra" otorgada por Lope Vázquez de Acuña, "camarero mayor de las armas del rey y del su Consejo", Fortaleza de Castil de Acuña, 30 enero 1480, AHN, Nobleza, Priego, C. 7 , D. 24 .
} 
Los donceles, a su vez, podían presentar mozos de espuela para servir en la corte $^{79}$.

Lope Ruiz de Alarcón había sido doncel de Juan II, según recoge su crónica, mientras que Lope Vázquez de Acuña y su hijo Juan de Acuña fueron donceles de los Reyes Católicos, por lo que cobraban 1.200 mrs. anuales ${ }^{80}$.

\section{OTROS CARGOS NO CORTESANOS}

Algunos miembros de la nobleza conquense también desempeñaron cargos fuera de la corte regia que tenían una función específica, de índole judicial, administrativa o eclesiástica. El Alcalde mayor de los hijosdalgo, el Alcalde mayor de las mestas o los consejeros reales eran designados por el monarca castellano; en cambio, el Adelantado de Cazorla, al ser jurisdicción eclesiástica, era un cargo elegido por los arzobispos toledanos.

\section{El Alcalde mayor de los fijosdalgo de Castilla}

Este oficio fue desempeñado por distintos señores conquenses a lo largo del siglo XV. Gómez Carrillo el Viejo, hijo de Álvaro Carrillo, consta en varios documentos de época de Enrique III y Juan II. Su nieto Gómez Carrillo de Albornoz recibió el título en 1417, con solo seis años de edad, y aparece en el desempeño de tal oficio en varios documentos de los años treinta $^{81}$ y en los libros de los contadores en 1455. A la muerte de Gómez Carrillo, en 1457, le sustituyó su hijo Juan de Albornoz:

Fiso el Rey merçed destos mrs. por su alualá firmado de su nonbre, fecho a xvii días de setienbre, año de IU cccclviii años, que tiene Ruy Gonsáles de Fuentedueña, a Juan de Albornos, fijo del dicho Gómes Carrillo de Albornos, de quien está su traslado en el libro de los traslados por fin e muerte del dicho su padre, que es finado ${ }^{82}$.

${ }^{79}$ M. Á. LADERO QUESADA, 1462: un año en la vida de Enrique IV, rey de Castilla, ob. cit., pp. 239, 247 y 262-263. Andrés de Cabrera recibió 30 doblas del rey para el juego de dados, que se realizaba en Nochebuena y los días siguientes. Además recibió 30 enriques de aguinaldo.

${ }^{80} 26$ marzo 1489, RAH, Salazar y Castro, D-13, fol. 50r-v. Lope Vázquez de Acuña tenía asentada esa cantidad el 21 de julio de 1481 y los había empezado a cobrar en 1478.

${ }^{81}$ Gómez Carrillo, "alcallde mayor de los fijosdalgos de los reynos de Castilla", se encontraba en una reunión que tuvo lugar en la capilla del obispo don Alvaro en la catedral dé Cuenca, junto al teniente de corregidor y algunos alcaldes y regidores para debatir cierta cantidad de maravedís que debía el concejo por el arrendamiento de la moneda forera, 30 noviembre 1403, AMC, leg. 4 , exp 2 publ. A. CHACÓN GÓMEZ-MONEDERO, Colección diplomática del Concejo de Cuenca, 1190-1417, Cuenca, 1998, doc. 177, p. 407. También aparece mencionado en un documento concejil de época de Juan II, 12 octubre 1417, AMC, leg. 185, exp. 1, fol. 18v, publ. A. CHACón GóMEZ-MONEDERO y P. MARTÍNEZ ESCRIBANO (dir. M. Jiménez Monteserín), Actas municipales del ayuntamiento de Cuenca (Años 1417, 1419 y 1420), Cuenca, 1994, p. 23.

En varios documentos del Archivo de la Villa de Madrid, el monarca recordaba a las villas y ciudades castellanas que respetaran a los oficiales y alcaldes designados por Gómez Carrillo de Albornoz, que alcanzó la mayoría de edad en 1432, T. PUÑAL FERNÁNDEZ, La ganadería lanar en Madrid y su tierra durante la Edad Media, "Espacio, Tiempo y Forma", 11 (1998), pp. 357 358.

${ }^{82} 17$ septiembre 1457, AGS, QC, leg. 4, fol. 189. 
Lope Vázquez de Acuña ocupó en 1466 el oficio de alcalde de los fijosdalgo en lugar de Juan de Albornoz, "así finado". La quitación anual se elevaba a $18.000 \mathrm{mrs}$ :

Fállase por este mismo libro de las quitaçiones del Rey, nuestro señor, deste año de IU cccclxvi años en cómo Juan de Albornos, allcalde mayor de los fijos de algo, tiene de quitaçión cada año con el dicho ofiçio xviii $U$. Por virtud de lo qual fueron puestos e asentados al dicho Lope Vásques e ge los han de librar este año enteramente en esta guisa ${ }^{83}$.

A finales del siglo XV el oficio pertenecía a Luis Carrillo de Albornoz, hijo de Pedro Carrillo de Albornoz, señor de Beteta y Torralba. Así figura en la documentación desde, al menos, el año 1495

Sepan quantos esta carta vieren cómo yo, doña Mençía de Mendoça, señora de las villas de Torralua e Veteta, muger que fue del señor Pedro Carrillo de Albornos, defunto, que santa gloria aya, por my e en nonbre e en bos de Luys Carrillo de Albornos, alcalde mayor de los fijosdalgo de Castilla, e de doña Ysabel de Mendoça, mis fijos e fijos del dicho señor Pedro Carrillo, e así como su tutora e curadora $[\ldots]^{84}$.

Conocemos un episodio en el que debió intervenir el Alcalde mayor de los fijosdalgo de Castilla para probar la hidalguía de un vecino de Cuenca. Gómez Carrillo protegió en 1403 a Gonzalo López en el pleito sobre la probanza de hidalguía que éste mantenía con el concejo de Cuenca. Gonzalo López denunció que le habían querido empadronar y pedido determinados tributos cuando era "omne fijodalgo de padre e de avuelo" - Francisco López y Gonzalo Rodríguez, respectivamente, cuya probanza había sido hecha en el reino de Aragón-. El concejo de Cuenca alegó que el procurador de Gonzalo López no había declarado los nombres del padre ni del abuelo, ni sabía de dónde procedía el linaje ni cuál era su solar conocido. La parte del interesado arremetió contra los testigos García Álvarez de Albornoz, Diego García de Jaraba y Juan Sánchez Paniagua porque le "querían mal vanal de muerte", mientras el procurador fiscal y el procurador del concejo respondieron que "eran en buena paz en concordia e buen amigos de la parte aversa". También alegaban que si "lo non prendavan ni pechava" era "por ruego de Gómez Carrillo" "55. En 1413 fueron Francisco López y Lope Sánchez de Huélamo,

${ }^{83} 6$ marzo 1466, AGS, OC, leg. 4, fol. 43. En esta fecha consta también como alcalde mayor de los fijosdalgo Sancho de Rojas, señor de las villas de Monzón y Cabia, H. CASADO ALONSO, $L a$ propiedad rural de la oligarquía burgalesa en el siglo XV, "En la España Medieval", 6 (1985), pp. 586-587.

${ }^{84}$ Guadalajara, 30 enero 1497, AGS, Cámara de Castilla, Personas, leg. 6, doc. 40. En 1495 Luis Carrillo de Àlbornoz era el titular de este oficio, según consta en una escritura redactada en Tendilla en la que su madre doña Mencía aparecía como su legítima tutora, Burgos, 30 febrero 1497, AGS, RGS, fol. 1.

${ }^{85} \mathrm{AMC}$, leg. 413, exp. 1, publ. A. CHACÓN GóMEZ-MONEDERO, Colección diplomática, ob. cit., doc. 179, pp. 411-420. La sentencia de Enrique III no se conoce porque el documento está incompleto. 
vecinos de Cuenca y familiares de Gonzalo López, quienes debieron probar su hidalguía,

seyendo omnes fijosdalgo de padre e de avuelo e devengar quinientos sueldos segund fuero de Castilla, porque el concejo e otros por su mandado, de quatro meses fasta entonçe, poco más o menos tiempo, que los avían enpadronado e fecho enpadronar e prendar injusta e non devidamente de çiertos bienes suyos [que estimó] en quinientos maravedís, por alguno de los dichos pechos e tributos en que non devían pechar los omnes fijosdalgo.

Alegaron que tenían "quatro e çinco mill ovejas e tenían omnes que las llevavan a los estremos e las trayan dellos", y no por ello perdían su hidalguía. El concejo presentó los mismos testigos que en el pleito anterior de Gonzalo López ${ }^{86}$.

\section{El Alcalde entregador mayor de las mestas y las cañadas}

La administración de justicia del Honrado Concejo de la Mesta recayó en los alcaldes entregadores mayores desde la fundación de la institución ganadera en época de Alfonso X. Los alcaldes debían defender los intereses de los pastores frente a los agricultores de los lugares y las aldeas por donde transcurrían las cañadas. A partir del reinado de los Reyes Católicos los pleitos e informes de sus actuaciones apenas quedaban recogidos por las instituciones locales, por lo que se institucionalizó la recopilación de la documentación referente a la Mesta en un $\operatorname{archivo~}^{87}$.

Entre los nobles conquenses, el primero en ejercer el oficio de alcalde mayor de mestas y cañadas mediante provisión real de 1415 fue Gómez Carrillo, que emitió una queja al monarca en la que decía que ni él ni sus alcaldes podían desempeñar sus funciones al no ser recibidos como tales ni ser respetados sus derechos y órdenes. No les querían

dar cadenas nin otras prisiones e cárceles en que tengan los presos e malfechores que prendieren, ni posadas en que posen sin dineros e viandas e todas las otras cosas que menester ovieren por sus derechos, e consentir que trayan armas en los lugares que por vos fueran vedadas ${ }^{88}$.

En 1417 concedió el oficio de Alcalde entregador del rey y del concejo de las mestas y cañadas a su tío y procurador Lope Vázquez de Acuña, señor de Azañón y Buendía:

${ }^{86}$ Fuente del Sango, 13 noviembre 1413, AMC, leg. 413, exp. 2, publ. ibídem, doc. 199, pp. 460-470. Juan II dio sentencia en que debía reunir a ambas partes y probar cada una de ellas sus afirmaciones.

${ }^{87}$ F. MARÍN BARRIGUETE, Archivo de la Mesta: tipologías documentales y posibilidades de investigación (sS. XVI-XVIII), "Cuadernos de Historia Moderna", 17 (1996), pp. 194-195.

${ }^{88}$ Valladolid, 10 octubre 1415, AMC, leg. 185, exp. 1, fol. s. n., publ. A. CHACÓN GóMEZMONEDERO y P'. MARTÍNEZ ESCRIBANO, Actas municipales, ob. cit., pp. 25-26. El documento tiene los folios $21 \mathrm{r}-\mathrm{v}$ y $22 \mathrm{r}$ en blanco. 
Sepan quantos esta carta de poder vieren, commo yo, Gómez Carrillo, alcallde mayor del Rey de los fijosdalgo de los Regnos de Castilla, e su alcallde entregador mayor de las mestas e cannadas en todos los sus regnos e sennoríos, otorgo e conosco que do e otorgo todo mi poder cunplido, segunt que mejor e más conplidamente lo puedo e devo dar de derecho, e segunt que lo yo he del dicho sennor Rey, a vos Lope Vázquez de Acuña, sennor de Azennón e de Buendía, e a los alcalldes e lugares tenientes que vos por vos en mi nombre pusiéredes ${ }^{89}$.

Las funciones del alcalde entregador eran "pronunçiar e mandar e judgar e sentençiar e llamar e enplazar e çitar e requerir e afrontar e protestar e prender e prendar e esecutar e enjuiciar". Pedían penas a quienes abrían, labraban o cerraban cañadas, caminos, veredas, ejidos, abrevaderos y confirmaban la creación de dehesas, así como elegir y revocar hasta tres alcaldes mayores en las ciudades y villas del obispado. El alcalde podía llevarse todo el ganado mostrenco - extraviado, sin dueño aparente- que se hallara en cualquier parte del reino castellano.

En 1425 Lope Vázquez de Acuña, en nombre de su sobrino Gómez Carrillo, puso a Pedro de la Cerda, guarda del rey, como Alcalde y entregador mayor de las mestas y cañadas. Unos meses después, Pedro de la Cerda traspasó este poder a Diego Gómez de Burguillos, alcalde ordinario de Badajoz, para que tuviera jurisdicción en todo el obispado de Badajoz ${ }^{90}$.

El titular del oficio, Gómez Carrillo, elevó una nueva protesta ante el Consejo Real en 1431, en la que exponía cómo "conçejos y personas singulares no le dejan usar el ofiçio, ni acoger en conçejos, villas y lugares", ni le permitían "oír, librar e terminar los pleitos" entre algunos de ellos y los pastores de la cabaña real y el Concejo de la Mesta, "ni hacer justiçia de robos e muertes y malefiçios que se fazen e son fechos a los pastores, e a sus ombres e familiares", mientras hacían entre ellos "conpusiçiones, ordenanzas, ligas y estatutos". El Consejo Real ordenaba en su provisión que le respetaran sus derechos, su salario, sus preeminencias, y sus usos y costumbres del oficio, según el ordenamiento hecho por el rey Alfonso $\mathrm{XI}^{91}$.

Pedro de Acuña fue designado por Juan II Alcalde y entregador mayor de las mestas y las cañadas. Enrique IV le concedió en 1454 la misma merced en sustitución de Gómez Carrillo, hijo de Álvaro Carrillo, quien lo había renunciado y traspasado en su primo Pedro de Acuña ${ }^{92}$. Este monarca volvió a confirmarle en 1465 el oficio para que lo tuviera de juro de heredad 24-25.

${ }^{89}$ Valladolid, 19 septiembre 1417, AMC, leg. 185, exp. 1, fol. 19v-20v, publ. ibídem, pp.

${ }^{90}$ Segovia, 10 noviembre 1425 y Cáceres, 24 marzo 1426, RAH, Salazar y Castro, M-5, fols. $165 \mathrm{r}-167 \mathrm{r}$.

${ }^{91}$ Palencia, 25 enero 1431, Á. PÉrez ChOZAs (ed.), Documentos del Archivo General de la Villa de Madrid, tomo II, Madrid, 1943, doc. XXX, pp. 153-157.

${ }^{92}$ Arévalo, 15 noviembre $1454, \mathrm{RAH}$, Salazar y Castro, D-13, fols. 3r-v y Arévalo, 19 diciembre 1454, ịbídem, D-13, fọls. 86r-87r y M-5, fol. $272 \mathrm{r}$. Juan II le instaba a usar la jurisdicción de la justicia civil y criminal que era propia al oficio: oír, juzgar y librar para hacer ejecución en las personas. 
perpetuamente para siempre jamás ${ }^{93}$. En 1477 doña Isabel y don Fernando, haciendo constar las mercedes precedentes de Juan II y Enrique IV, le renovaron en el oficio, con la posibilidad de delegar en un lugarteniente que disfrutaría todos los derechos y prerrogativas a él anexas. En 1478 Pedro de Acuña se dirigió a los monarcas por el agravio que él consideraba de ciertos capítulos que menoscababan su jurisdicción y preeminencia frente al Concejo de la Mesta, en concreto en el asunto de los cobros de derechos, salarios, ganados mesteños, penas y caloñas:

\begin{abstract}
Don Fernando e doña Ysabel, por la graçia de Dios, etc., por quanto vos, don Pedro de Acuña, conde de Buendía e del nuestro Consejo, nos fesystes relaçión quel señor rey don Juan, nuestro padre de gloriosa memoria, os ovo fecho merçed de allcaldía e entregador mayor e cañadas de las mestas de los términos destos nuestros regnos, la qual dicha merçed vos fue después confirmada e mandada guardar por el rey don Enrrique, nuestro hermano [...]. E por la presente vos confirmamos e aprouamos la dicha merçed que por el dicho rey don Juan vos fue fecha $[\ldots]^{94}$.
\end{abstract}

En este período y de forma reiterada aparecía Alfón de la Muela, escribano de la ciudad de Huete, como Alcalde entregador de la Mesta por Pedro de Acuña ${ }^{95}$.

También disfrutaron del cargo su hijo Lope Vázquez de Acuña desde 1480 y su nieto Juan de Acuña, que sustituyó a aquel a su muerte en $1489^{96}$. En la confirmación a Lope Vázquez de Acuña efectuada en 1488, los monarcas le indicaban la necesidad de corregir aquellas prácticas denunciadas ante la Corona, como las irregularidades en el nombramiento de lugartenientes: éstos debían ser personas “ábiles, abonadas e suficientes”; tenían que jurar la correcta administración de justicia, sin llevar demasiados derechos; por último, tenían la prohibición de hacer acuerdos ilegales y confirmar dehesas a concejos o personas particulares ${ }^{97}$. Juan de Acuña,

conde de Buendía, acatando los muchos e buenos seruiçios que don Lope Vásques de Acuña, conde de Buendía, adelantado de Caçorla, vuestro padre, nos fiso, y esperamos que vos nos fareys de aquí adelante y en alguna hemienda e remuneraçión dellos, tenemos por bien y es nuestra

\footnotetext{
${ }^{93}$ Salamanca, 20 mayo 1465, RAH, Salazar y Castro, D-13, fols. 87r-88r.

${ }^{94}$ Madrid, 6 marzo 1477, AGS, RGS, fol. 210 y RAH, Salazar y Castro, D-13, fol. 88r-v y Madrid, 18 abril 1478, ibídem, fol. 89r-v.

${ }^{95} \mathrm{~J} . \mathrm{M}^{\mathrm{a}}$ SÁNCHEZ BENITO, El poder en una pequeña ciudad castellana: el ejemplo de Huete en el siglo XV, "En la España Medieval”, 25 (2002), p. 193. Alfón de la Muela celebraba, más adelante, "con procesión y toda solemnidad, la fiesta de la Ascensión, incluyendo el oficio de difuntos por Gómez Carrillo de Albornoz y su mujer".

${ }^{96}$ Los Reyes Católicos solicitaron a Lope Vázquez de Acuña que "seades nuestro alcalde e entregador mayor de las Mestas e Cañadas en el reino de Castilla en lugar de Pedro de Acuña [...]. E podáis nlevar todos los derechos e salarios, e mostrenco e mesteño e otras cosas a su oficio de alcaldía”, Medina del Campo, 16 septiembre 1480, RAH, Salazar y Castro, D-13, fol. 112r-v.

${ }^{97}$ Zaragoza, 31 enero 1488, AGS, RGS, fol. 247, cit. M ${ }^{\text {a }}$ C. QuINTANILLA RASO, El pastoreo en Cuenca a fines de la Edad Media. Bases y logicas de un sistema económico en la compleja realidad agraria, en J. Gómez-Pantoja (ed.), Los rebaños de Gerión. Pastores y trashumancia en Iberia antigua y medieval, Madrid, Collection de la Casa de Velázquez, 2001, nota 55, p. 60. Véase apéndice documental.
} 
merçed que agora, e de aquí adelante, para en toda vuestra vida, seays nuestro alcalde y entregador mayor de las mestas y cañadas destos nuestros reynos y señoríos de Castilla e de León en lugar e por vacaçión del dicho conde don Lope Vásques de Cuña, vuestro padre, por quanto es finado e pasado desta presente vida. E por esta nuestra carta mandamos al conçejo de la mesta e cañadas destos dichos nuestros reynos y a todos los dueños de ganados y pastores y rabadanes e mayorales, e otras quales quier personas de los que agora son o serán de aquí adelante, que los reciban e ayan e tengan por nuestro alcalde e entregador mayor de las dichas mestas e cañadas de los dichos nuestros reynos e señoríos. E vsen con vos en el dicho ofiçio e con vuestros lugares tenientes, e os den e recudan, e fagan dar e recudir con todos los derechos e salarios e otras cosas al dicho ofiçio anexas e pertenesçientes. E que por rasón dél podedes e deuedes aver e leuar, e los guarden e fagan guardar todas las onras e graçias e merçedes e franquesas e libertades e preuillejos, e todas las otras cosas e cada vna dellas que por rasón del dicho ofiçio podedes e deuedes aver e gosar e vos deuen ser guardadas [...]. E vos damos la posesión e casy posesión dél e poder, e avtoridat, e conplida facultat para lo vsar e exerçer por vos e por vuestros lugares tenientes, en caso que por el dicho conçejo de la dicha mesta e cañadas de los dichos nuestros reynos e señoríos, ni por los dueños de ganados e otras personas suso dichas dellos, a él non seades resçebidos. Y por esta nuestra carta o por su traslado sygnado de escribano público, mandamos al yllustre prínçipe don Juan, nuestro muy caro e muy amado fijo, e a los ynfantes, duques, prelados, marqueses, condes, ricos onbres, maestres de las órdenes, priores, comendadores e subcomendadores, alcaldes de los castillos e casas fuertes e llanas, e a los del nuestro Consejo e oydores de la nuestra avdiençia, alcaldes, alguasiles, e notarios e otras justiçias e ofiçiales quales quier de la nuestra casa e corte e chancillería, e atodos los conçejos e corregidores, asystentes, alcaldes, alguasiles, merinos, regidores, jurados, caballeros, ofiçiales y onbres buenos de todas las çibdades, e villas e lugares de nuestros Reynos e señoríos, e otras quales quier personas, nuestros vasallos e súbditos e naturales de qual quier ley, estado, preheminençia o dignidat que sean, e a cada vno dellos que agora son o serán de aquí adelante, que los guarden e cunplan, e fagan guardar e cunplir esta nuestra carta e la merçed en ella contenida, según que de suso en esta nuestra carta se contiene, e declara e vos defiendan e anparen en ella. E contra el tenor e forma della ni de lo en ella contenido vos non vayan, ni pasen, ni consientan yr ni pasar en tienpo alguno ni por alguna manera, cavsa ni rasón ni color que sea o se r pueda. E los vnos ni los otros non fagades ni fagan ende al por alguna manera, so pena de la nuestra merçed e de dies mill maravedís para la nuestra cámara. E cada vno por quien fyncare de lo asy faser e conplir. E demás mandamos al ome que les esta nuestra carta mostrare que los enplase que parescan ante nos en la nuestra corte, do quier que nos seamos, del día que los enplase fasta quinse días primeros siguientes so la dicha pena, so la qual mandamos a qual quier escribano público que para esto fuere llamado, que dé ende al al que la mostrare testymonio sygnado con su signo por que nos sepamos en cómo se cunple nuestro mandado ${ }^{98}$.

${ }^{98}$ Juan de Acuña recibió el título “por quanto” su padre Lope Vázquez de Acuña “es finado y pasado desta presente vida". La merced de la alcaldia mayor de las entregas de la Mesta le fue concedida en Medina del Campo, 26 marzo 1489, AGS, RGS, fol. 51 y RAH, Salazar y Castro, D-13, fol. $118 \mathrm{r}-\mathrm{v}$. 
Juan de Acuña protestó poco después porque limitaron tanto sus facultades y poderes, que él y sus lugartenientes no tenían facultad para hacer justicia a los del Concejo de la Mesta, por lo que solicitó merced a la reina Isabel para usar su oficio

con las esençiones e facultades del prebilejo que yo tengo del dicho ofiçio, e conforme a él, segund e como lo vsaron los otros alcaldes e entregadores, mis anteçesores que an tenydo e vsado el dicho ofiçio antes que yo, syn enbargo de las limitaçiones e dudas fechas por los del vuestro Consejo ${ }^{99}$.

En 1498 Juan de Acuña pleiteó con el Concejo de la Mesta sobre la propiedad de los ganados mesteños ${ }^{100}$.

\section{El Adelantamiento de Cazorla}

El Adelantamiento de Cazorla era un señorío eclesiástico de los arzobispos de Toledo, asentado en la línea fronteriza con el reino de Granada $\mathrm{y}$, consecuentemente, con una primordial función militar. La Corona castellana empleó el sistema de los adelantamientos en las zonas de frontera, donde los prelados toledanos no podían asumir personalmente la defensa del territorio $^{101}$. Los adelantados de Cazorla eran designados por los arzobispos, que delegaban sus funciones en algún familiar o algún personaje de la corte, aunque de forma excepcional la influencia del monarca se impuso en algún caso. Los adelantados debían cumplir el ritual del pleito homenaje hacia los arzobispos y, posteriormente, comenzaba a nombrar a los otros oficiales del señorío.

Pedro de Acuña, primer conde de Buendía, y su hijo Lope Vázquez de Acuña, fueron adelantados de Cazorla. El primero desempeñó el cargo bajo el mandato de su hermano don Alfonso Carrillo de Acuña (1446-1482), hijo de Lope Vázquez de Acuña, que había sido nombrado en lugar de Lope de Barrientos, obispo de Cuenca, por la insistencia de su pariente el condestable

\footnotetext{
99 “Muy poderosa señora: Don Juan de Acuña, conde de Buendía, veso las manos de vuestra alteza", s. f., AGS, Cámara de Castilla, Personas, leg. 152, doc. 202.

${ }^{100}$ Madrid, 12 enero 1498, AGS, RGS, fol. 122. En este año aparecen Pedro de Gavarcos y Luis González de Sepúlveda como alcaldes entregadores de las cañadas reales por el conde de Buendía, Valladolid, 20 septiembre 1498, AGS, RGS, fol. 81 y Valladolid, 5 octubre 1498, AGS, RGS, fol. 71.

${ }^{101}$ Las principales villas del Adelantamiento durante la Baja Edad Media fueron Cazorla, Quesada, Iznatoraf, La Iruela, Villanueva del Arzobispo y Villacarrillo. Son fundamentales los estudios de J. F. RIVERA RECIO, El Adelantamiento de Cazorla. Historia General, Toledo, 1948 y, especialmente, $\mathbf{M}^{\mathrm{a}}$ del M. GARCÍA GUZMÁN, El Adelantamiento de Cazorla en la Baja Edad Media. Un señorio eclesiástico en la frontera castellana, Universidad de Cádiz, 1985. Sobre el mismo ámbito temático y geográfico son los trabajos de la profesora $\mathrm{M}^{\mathrm{a}}$ del M. GARCÍA GUZZMÁn, Colección Diplomática del Adelantamiento de Cazorla (1231-1495), Cádiz, 1991; Régimen municipal en el Adelantamiento de Cazorla, "Boletín del Instituto de Estudios Giennenses", 168 (1998), pp. 99-121; Ubeda y Cazorla en la Baja Edad Media: enfrentamientos por el control del espacio en el alto Guadalquivir, en Estudios sobre Patrimonio, Cultura y Ciencias Medievales, vol. I Cádiz, 1999 pp. 77-96 y La guerra de Granada en las probanzas de hidalguía: los Amador de Lezcano, hidalgos de Cazorla y Quesada, "Anuario de Estudios Medievales", 32/1 (2002), pp. 333-359.
} 
Álvaro de Luna. Pedro de Acuña fue nombrado adelantado de Cazorla en 1448, tras la destitución de don Pedro de Toledo ${ }^{102}$.

Lope Vázquez de Acuña fue nombrado adelantado de Cazorla por don Alfonso Carrillo de Acuña hacia 1455 y también ejerció el oficio bajo el arzobispo Pedro González de Mendoza (1482-1495), hasta 1486 aproximadamente. La donación del Adelantamiento por parte del arzobispo toledano, su hermano, fue confirmada por los monarcas y los papas Paulo II y Sixto IV, "quienes se la alargaron por los días de su vida". Los reyes confirmaron la donación por los servicios de su padre Pedro de Acuña y por los suyos propios en la guerra con Portugal y con los moros, especialmente durante la batalla en Quesada, "donde tan extrema e verilmente venció con mui poca gente, prendiendo e matando muchos dellos" ${ }^{103}$. Don Fernando y doña Isabel también intervinieron ante la Santa Sede para que el papa Sixto IV confirmase su nombramiento en 1477, puesto que Alfonso Carrillo había determinado que el oficio sería vitalicio, cláusula que debía ratificar el papa romano. Sixto IV confirmó el privilegio otorgado por Alfonso Carrillo a su sobrino Lope Vázquez de Acuña el 13 de marzo de 1477, que ya había sido concedido por bula papal de Paulo II el 21 de septiembre de 1470:

Mui santo Padre, el Rey é la Reyna de Castilla, de León, de Sicilia, de Portugal, Príncipes de Aragón, mui humildes e debotos fijos de vuestra Santidad, besamos vuestros pies y santas manos, y nos encomendamos en vuestra Beatitud, a la qual plega saber que don Lope Vázquez de Acuña, Adelantado de Cazorla, de nuestro Consejo, embía a vuestra Santidad el llebador de la presente a le suplicar algunas cosas que al dicho Adelantado cumple. E por que allende de lo que cumple a él, es mui cumplidero a la defensión e reposo destos nuestros Reynos, por el dicho Adelantado ser la persona que es, y estar aquel Adelantamiento en la frontera del Reyno de Granada, a vuestra Santidad mui humildemente suplicamos que las cosas del dicho Adelantado mande bien despachar e aver por encomendadas. E allende que en ello Dios nuestro señor será mucho servido, nos lo reciviremos en señalada merced é beneficio de vuestra Santidad, cuia vida y estado nuestro señor por luengos tiempos acreciente á bueno e próspero regimiento de la su universal Iglesia. De vuestra Santidad mui humilde e deboto fijo, que vuestros santos pies y manos besa. El Rey de Castilla, León, Sicilia y Portugal. De vuestra Santidad mui humilde e debota fija, que vuestros santos pies y manos besa. La Reyna de Castilla, León, Sicilia y Portugal. A nuestro mui santo Padre ${ }^{104}$.

\footnotetext{
${ }^{102}$ Pedro de Acuña había sido nombrado adelantado el 26 de mayo de 1448, según un documento datado en Alcalá de Henares, M ${ }^{\text {a }}$ del M. GARCíA GUZMÁN, El Adelantamiento de Cazorla en la Baja Edad Media, ob. cit., nota 90, p. 154. Sobre Alfonso Carrillo de Acuña consúltese el trabajo de J.M. NIETO SORIA, Dos prelados en la encrucijada de un trono: Alfonso Carrillo de Acuña y Pedro González de Mendoza,"Torre de los Lujanes, Boletín de la Real Sociedad Económica Matritense de Amigos del País", 54 (2004), pp. 49-64.

${ }^{103}$ S.f., RAH, Salazar y Castro, D-13, fol. 108v-109v.

${ }^{104}$ Madrid, 13 marzo 1477, RAH, Salazar y Castro, D-13, fol. 104r-v; J. F. RIVERA RECIO, El Adelantamiento de Cazorla. Historia General, ob.cit., p. 73 y Ma del M̀. GARCÍA GUZMÁN, El Adelantamiento de Cazorla en la Baja Edad Media, ob. cit., pp. 79 y 138-140.
} 
En 1481 Lope Vázquez de Acuña tenía 54.000 mrs. anuales para 36 lanzas, que le fueron asentadas al renunciarlas su padre en 1458; posteriormente, en 1489, esta cantidad le fue traspasada a su hijo Juan de Acuña ${ }^{105}$.

Las atribuciones de los adelantados de Cazorla eran jurisdiccionales, militares y gubernativas. Podían administrar justicia, salvo en determinados casos reservados al arzobispo. Así, en 1478 Lope Vázquez de Acuña perjudicó los intereses de Cazorla en un pleito por aprovechamiento de términos con $\mathrm{La}$ Iruela, y en 1479 ordenó a los alcaldes de Villanueva levantar las penas que habían impuesto.

Para la defensa militar del territorio de Cazorla, el adelantado nombraba a los alcaides de las fortalezas y dirigía las milicias concejiles en sus intervenciones. Lope Vázquez de Acuña derrotó en 1469 a las tropas musulmanas que cercaron la villa de Quesada con 900 jinetes y 3.000 peones, obteniendo muchos prisioneros ${ }^{106}$, y en 1484, coincidiendo con la presencia de la reina doña Isabel en Jaén, ordenó a los concejos de Villacarrillo, Villanueva del Arzobispo e Iznatoraf que prepararan sus contingentes militares.

Respecto al gobierno del Adelantamiento, su función era el nombramiento de oficiales concejiles, que quedaba limitado por los privilegios forales. Los oficiales eran el lugarteniente, los alcaldes mayores y los alcaides. Martín de Avendaño fue lugarteniente de Pedro de Acuña; y podía nombrar oficiales del Adelantamiento, solicitar contribuciones extraordinarias o reunir información sobre el aprovechamiento comunal de los términos. Los dos alcaldes mayores auxiliaban al adelantado en sus funciones judiciales y los alcaides recibían la tenencia de las fortalezas del señorío.

Entre los derechos y retribuciones percibidos, los más significativos eran las rentas por desempeñar el oficio. En el nombramiento de Pedro de Acuña se introdujo una cláusula por la que una determinada cantidad de las rentas percibidas se destinaría al mantenimiento de las fortalezas del señorío. Otros oficiales del Adelantamiento fueron el gobernador, el fiscal, el corregidor y el juez pesquisidor ${ }^{107}$.

Entre otras actuaciones significativas de los adelantados Acuñas sobre aspectos militares, destacan la regulación de las ganancias lícitas en caso de rescate de un vecino del Adelantamiento y la excepcional intervención en el rescate de cautivos ${ }^{108}$. En la administración local, Lope Vázquez de Acuña

${ }^{105} 26$ marzo 1489, RAH, Salazar y Castro, D-13, fol. 50r-v. Lope Vázquez de Acuña tenía asentada esa cantidad el 26 de julio de 1481 como Adelantado de Cazorla.

${ }^{106}$ La batalla del cerco de Quesada tuvo lugar el 10 de marzo de 1469. Las tropas cristianas del arzobispo - acaudilladas por Pedro de Acuña y su hijo Lope Vázquez de Acuña- y las musulmanas del rey de Marruecos se enfrentaron en El Retamar. De los 3.500 atacantes perecieron 700, Lope Vázquez de Acuña persiguió a los que huyeron y les arrebató 2.500 caballos y 13 banderas, que en adelante orlarían el escudo de don Lope y la Iglesia de la Merced de Cazorla, ibídem, p. 72.

${ }^{107} \mathrm{M}^{\mathrm{a}}$ del M. GARCÍA GuZMÁN, El Adelantamiento de Cazorla en la Baja Edad Media, ob. cit., pp. 84-86, 156-161 y 164-177.

${ }^{108}$ El 10 de julio de 1489 Antón de la Fuente, adalid, vecino de Cazorla, presentó una demanda contra el conde de Buendía - ya difunto - porque él y otros vecinos cautivaron a Farax, adalid en Baza, vendiéndolo posteriormente al conde de Buendía por 13.500 mrs. Luego el dicho Antón de la Fuente cayó prisionero y se estableció su canje por Farax; el adalid de Cazorla tuvo 
informó en 1474 al arzobispo Alfonso Carrillo de que el oficio de jurado se había convertido en perpetuo en la villa de Cazorla, cuando debía echarse a suertes. En 1478, por orden del arzobispo, intervino en un asunto de beneficios económicos derivados de la explotación de términos comunales entre Cazorla y La Iruela, e hizo cumplir el privilegio que poseía esta última villa de obtener la cuarta parte del total de los beneficios ${ }^{109}$. Por otra parte, la ciudad de Úbeda le demandó ciertas fianzas para asegurarse que los moros no atacarían el lugar por un carril creado en los montes de Quesada, cuyo objetivo era facilitar la corta de leña que en ellos podían hacer con licencia ${ }^{110}$.

\section{Los consejeros reales}

Diego Hurtado de Mendoza y Juan Hurtado de Mendoza pertenecieron durante los reinados de Juan II, Enrique IV y de Isabel al Consejo Real ${ }^{111}$, que era un órgano de asesoramiento en asuntos políticos y judiciales concretos. Según las ordenanzas de Valladolid de 1385, fecha en la que fue creada esta institución, los consejeros eran cuatro prelados, cuatro nobles y cuatro representantes de las ciudades, aunque el número de integrantes osciló en periodos posteriores. Las funciones de este organismo y sus formas de actuación quedaron recogidas en unos ordenamientos del rey Enrique III, que también determinó en dieciséis el número de consejeros ${ }^{112}$. Los representantes de las ciudades fueron sustituidos por doctores en leyes, que ya fueron prevalecientes en el Consejo a partir del reinado de los Reyes Católicos, al nombrar para su composición a personas de formación jurista. Hasta entonces, la nobleza había tenido una presencia mayor en el Consejo Real para intentar controlar el gobierno del reino, especialmente la distribución de la renta de la corona. Probablemente, Juan Hurtado de Mendoza fue designado consejero a

que comprar al adelantado el adalid granadino, por el que le pidió $89.000 \mathrm{mrs}$., teniendo que vender todos sus bienes para obtener su liberación. La protesta se basaba en una ordenanza por la que el propietario de un esclavo musulmán canjeable por un cristiano del Adelantamiento solo podía pedir un tercio más de su precio de compra. Los Reyes Católicos ordenaron al entonces adelantado Hurtado de Mendoza que hiciera justicia al adalid Antón de la Fuente, ibídem, pp. 213-214. En 1476 Lope Vázquez de Acuña solicitó el envío de dos moros, vecinos de Huesa, que fueron cautivados por almogávares cristianos en período de treguas y que habían sido vendidos en Jaén, para devolverlos al reino granadino, ibídem, p. 215.

${ }^{109}$ Ibídem, pp. 245, 250 y 261-262. Los concejos de Cazorla y La Iruela debatieron por mantener sus privilegios en años sucesivos, hasta que en 1497 alcanzaron una concordia.

${ }^{110}$ Medina del Campo, 13 septiembre 1480, AGS, RGS, fol. 242.

111 "Diego Furtado de Mendoça, mi Montero maior e del mi Consejo", 30 agosto 1437, RAH, Salazar y Castro, M-95, fol. 85v; "Juan Furtado de Mendoça, del mi Consejo e mi guarda mayor de la çibdad de Cuenca", AGS, RGS, 15 noviembre 1475, doc. 740.

${ }^{112}$ E. MITRE FERNÁNDEZ, Mecanismos institucionales y poder real en la Castilla de Enrique III, "En la España Medieval. Estudios dedicados a Julio González", 1 (1980), pp. 322-324. Entre otras disposiciones, se exponía que la cámara del Consejo estuviera donde morara el rey, que en caso de no llegar a un acuerdo en las deliberaciones - que no debían exceder de tres horas salvo casos excepcionales - el monarca tuviera la última palabra y que se guardara registro de todas las peticiones, atendidas conforme iban llegando. 
título honorífico, por razón de su dignidad y de sus oficios; por ello, no cobraba quitación ni residía en el Consejo ${ }^{113}$.

Otros nobles conquenses también pertenecieron al Consejo Real, como Lope Vázquez de Acuña, señor de Azañón, durante el reinado de los Reyes Católicos ${ }^{114}$, quienes en las Cortes de Toledo en 1480 completaron el funcionamiento de la institución.

\section{CONCLUSIONES}

Para la nobleza conquense del siglo XV las relaciones de colaboración con el rey le permitieron afianzar un interesente patrimonio señorial gracias a las concesiones de títulos y cargos cortesanos. Las principales características de estos oficios regios, cuyas funciones primordiales han quedado apuntadas en sus líneas generales, eran su designación regia, la retribución económica en un salario anual y unas rentas "situadas" y su transmisión hereditaria, aunque en la práctica quedaban vacíos de contenido y en ocasiones eran meramente honoríficos. De los cargos analizados, sobresalieron de forma especial, entre los cortesanos, el oficio de Montero mayor, desempeñado a partir del siglo XV por los Hurtado de Mendoza, señores de Cañete, que demuestra la cercanía personal al monarca de determinados personajes nobiliarios, y la alcaldía mayor de las mestas y cañadas, asignada al linaje Acuña, condes de Buendía, espolón de los nuevos intereses económicos que fue asumiendo la nobleza tardomedieval. Incluso, según hemos tenido ocasión de comprobar, algunos de estos nobles conquesnses asumieron el desempeño de varios oficios de forma simultánea.

A través del ejemplo paradigmático de los linajes conquenses, ha quedado plasmada la posición relevante de la nobleza castellana en el ejercicio del poder político, incluso en un contexto en el que se ha ensalzado el camino hacia la centralización del aparato gubernativo del Estado moderno. Como algunos autores han puesto de relieve, la nobleza castellana "se introdujo en un modelo de organización política bipolar (rey/reino) como instancia intermedia, hasta llegar a configurar un modelo tripular (rey/poderes fácticos/reino), que funcionaba de hecho, sobre la base del papel preeminente de sus integrantes" 115 . La política era para la nobleza, en palabras de otro insigne medievalista, "una vocación y una necesidad" $" 16$.

${ }^{113}$ S. de Dios, El Consejo Real de Castilla (1385-1522), Madrid, 1982, especialmente pp. 105-115 y 254-302. Juan Hurtado de Mendoza, Mayordomo mayor de Juan II y padre del primer señor de Cañete, tuvo gran peso en el Consejo Real, ibídem, p. 123.

${ }^{114}$ Fortaleza de Castil de Acuña, 30 enero 1480, AHN, Nobleza, Priego, C. 7, D. 24.

${ }^{115}$ M.C. QUINTANILla RASO, El protagonismo nobiliario en la Castilla bajomedieval. Una revisión historiográfica (1984-1997), "Medievalismo", 7 (1997), p. 200.

${ }^{116}$ L. SUÁREZ FERNÁNDEZ, Nobleza y monarquía. Entendimiento y rivalidad, Madrid, La Esfera de los Libros, 2003. 


\section{APÉNDICE DOCUMENTAL}

1488, enero, 31. Zaragoza.

Los Reyes Católicos se dirigen a Lope Vázquez de Acuña, Alcalde entregador mayor de las mestas y cañadas, para ordenarle cómo deben actuar sus lugartenientes en el desempeño del oficio.

AGS, Registro General del Sello, Zaragoza, 31 enero 1488, fol. 247.

Don Fernando e doña Isabel, etc. A vos don Lope Vásques de Acuña, conde de Buendía, adelantado de Caçorla, del nuestro Consejo e nuestro alcalde entregador mayor de las mestas y cañadas, e a vuestros alcaldes e lugares tenientes, y a cada una e qual quier de los a quien esta nuestra carta fuere mostrada o el traslado della sygnado de escribano público, salud e graçia. Sepades que por çiertas quexas que nos fueron dadas de los lugares tenientes de vos, el dicho conde, en el ofiçio de alcaldía mayor de las dichas mestas y cañadas, nos mandamos faser çierta pesquisa en el marquesado de Villena y en otras partes, la qual fue trayda ante nos, e asimismo los preuillejos e ordenanças por donde se regía e devía regir el dicho ofiçio de la dicha alcaldía, e mandamos aver e fue avida información çerca del vso e guarda dellas. E todo visto en el nuestro Consejo fue acordado escusar estorsiones e agravios que nuestros súbditos e naturales recibían a cavsa del dicho ofiçio de vuestros lugares tenientes, que se deuía de proueer en la forma syguiente:

Primeramente, que ningún lugar teniente no pueda ir a vsar y exerçer el dicho ofiçio saluo a pedimiento de la dicha mesta o de procurador espeçial al que para esto tenga poder e sobre agrauios e cosas ciertas. E que en tal caso vaya el dicho vuestro lugar con vuestro poder a vsar el dicho ofiçio en aquellas cosas para que fuere requerido e no en otras. E quel dicho vuestro lugar teniente no pueda dar poder a otro para que faga cosa alguna que toque al dicho ofiçio. E lo que contra esto fuere fecho que sea en sy ninguno y el que lo fisiere sea ynabile para vsar este ofiçio ni otro alguno.

Yten que vos ni los dichos vuestros lugares tenientes no podays confirmar ni confirmeys dehesas algunas a ningunos concejos ni personas particulares de nuestros rey- // [fol. 1v] nos, ni faser otras de nuevo ni por rasón dello lleuar derechos algunos. E si de fecho lo fisieredes o fisieren que sea en sy ninguno. E quel que lo procurare aya e yncurra en pena de veynte mill maravedís para que sean dados a nuestro limosnero para destribuyr en obras pías y quel alcalde que contra esto fuere o pasare pague lo que lleuare con las sentençias e sea ynabile para aver el dicho ofiçio.

Yten que quando vos, el dicho conde, oviéredes de [en blanco] algún lugar teniente que primero y ante todas cosas tome consygo un alcalde de la çibdat, o villa o lugar donde fuere a vsar y exerçer el dicho ofiçio e amos a dos juren solepnemente de guardar la justiçia a las partes e faser bien e fielmente lo que devieren. E que no lleuaran derechos demasiados a ningún otro conçejo ni persona particular. E que no lleuaran penas algunas sin la parte llamada, e oyda e condenada por sentençia. E la tal sentençia pasada en cosa judgada y esecutado aquello por que fuere dada la dicha sentençia. E que estonçes el acompañado del dicho vuestro lugar teniente no lleue 
parte ni derechos algunos de las dichas penas, e quel escribano que con él fuere non lleue salario alguno saluo sus derechos como los lleuan los escriuanos de los alcaldes ordinarios de la çibdat, villa o lugar do exerçiere el dicho ofiçio, todo so las dichas penas.

Yten que el dicho vuestro lugar teniente non pida, ni demande ni lleue la costa que fisiere a los lugares donde fuere, ni tome dádiva ni presente saluo sus derechos a las penas en que condenare, como dicho es, so las dichas penas.

Yten por quanto en las ordenanças por donde se a de vsar el dicho ofiçio ay en muchos capítulos pena de çient maravedís de los buenos e ay dubda a quánto se a de pagar por estos çien maravedís, por ende, conformándonos con el valor de la moneda de estonçes e con la de agora, e con las leyes de nuestros Reynos que sobre esto fablan, mandamos que por çien maravedís de los buenos, se lleuen seisçientos maravedís de los que agora corren o corrieren de aquí adelante, e no más ni allende. Yten quel dicho vuestro alcalde no pueda faser yguala ni contenençia con persona alguna, ni lleuar pena antes de ser roturado e restituydo las cañadas, e heredamientos, e dehesas e otras cosas que fallaren que están tomadas e ocupadas de lo público e conçejil. E que tornado e restituydo lo suso dicho, puedan lleuar las penasen que fueren condepnados quales quier conçejos e personas e dellas [...] lo que quisiere so las penas. //

[fol. 2r] Porque vos mandamos que con las limitaçiones suso dichas e con cada vna dellas vseys y fagays vsar el dicho ofiçio a vuestros lugares tenientes e pongays para ello personas ábiles, e sufiçientes, e abonadas e tales que den cuenta e rasón de lo que deuieren faser de aquí adelante. E mandamos a todos los conçejos, justiçias, regidores, caballeros, escuderos, ofiçiales y onbres buenos de todas las çibdades, e villas e lugares de los nuestros reynos y señoríos que esta nuestra carta de declaraçión guarden e cumplan. E guardando lo en ella contenydo, los dexen e consienten a vos e a vuestros lugares tenientes vsar del dicho ofiçio según e por la vía, e forma e manera que se contiene en las cartas e prouisyones que de nos para ello tenes. E que esta nuestra declaraçión e que qual quier procurador que la mesta enviare a cosas generales de las mestas e cañadas lleue consygo el traslado desta nuestra carta, e que asy mismo lo lleue el vuestro lugar teniente. E los vnos ni los otros non fagades ende al so pena de la nuestra merced e de dies mill maravedís para la nuestra cámara. Además mandamos al omne que vos esta nuestra carta mostrare que vos enplase que parescades ante nos en la nuestra corte do quier que nos seamos, del día que vos enplasare fasta quinse días primeros siguientes so la dicha pena, so la qual mandamos a qual quier escribano público que para esto fuere llamado que dé ende al que ge la mostrare testimonio sygnado con su sygno, por que nos sepamos en cómo se cunple nuestro mandado. Dada en la çibdat de Çaragoça, a treinta e vn días del mes de enero, año del nasçimiento del nuestro señor Iehuxristo de mill y quatroçientos y ochenta y ocho años. Yo el Rey, yo la Reyna. Yo Diego de Santander, secretario del rey e de la Reyna, nuestros señores, la fis escreuir por su mandado. Rúbrica. [...]. Johanes doctor, Andrés doctor, Alonso doctor.

Fecha de recepción del artículo: mayo 2007

Fecha de aceptación y versión final: agosto 2007. 